\title{
Nutrition Accountability through Sub-National Scorecards in Tanzania - Policy Innovations and Field Realities
}

Rishiraj Bhagawati, Dolf J.H. te Lintelo, John Msuya and Tumaini Mikindo 
The strategic partnership between Irish Aid and Institute of Development Studies focuses on social protection, food security and nutrition. The collaboration brings together research and capacity development with policy, programmatic and influencing know-how to support action that more effectively reduces poverty and injustice. The aim of the partnership is to combine cutting edge evidence and learning to support implementation of Ireland's policy for international development, A Better World.

(C) Institute of Development Studies 2021

Nutrition Accountability through Sub-National Scorecards in Tanzania - Policy Innovations and Field Realities Rishiraj Bhagawati, Dolf J.H. te Lintelo, John Msuya and Tumaini Mikindo December 2021

First published by the Institute of Development Studies in December 2021 ISBN: 978-1-78118-899-6 DOI: 10.19088/IDS.2021.067

Suggested citation: Bhagawati, R.; te Lintelo, D.J.H.; Msuya, J. and Mikindo, T. (2021) Nutrition Accountability through Sub-National Scorecards in Tanzania - Policy Innovations and Field Realities, Brighton: Institute of Development Studies, DOI: 10.19088/IDS.2021.067

A catalogue record for this publication is available from the British Library

This paper has been produced thanks to funding by Irish Aid from the Government of Ireland. The opinions expressed here belong to the authors, and do not necessarily reflect those of Irish Aid or IDS.

This is an Open Access paper distributed under the terms of the Creative Commons Attribution Non Commercial 4.0 International licence (CC BY-NC), which permits use, distribution and reproduction in any medium, provided the original authors and source are credited, any modifications or adaptations are indicated, and the work is not used for commercial purposes.

Available from:

Institute of Development Studies, Library Road

Brighton, BN1 9RE, United Kingdom

$+44(0) 1273915637$

ids.ac.uk

IDS is a charitable company limited by guarantee and registered in England

Charity Registration Number 306371

Charitable Company Number 877338 
Working Paper

\section{Nutrition Accountability through Sub-National Scorecards in Tanzania - Policy Innovations and Field Realities}

Rishiraj Bhagawati, Dolf J.H. te Lintelo, John Msuya and Tumaini Mikindo December 2021 


\title{
Nutrition Accountability through Sub-National Scorecards in Tanzania - Policy Innovations and Field Realities
}

\author{
Rishiraj Bhagawati, Dolf J.H. te Lintelo, John Msuya and Tumaini Mikindo \\ December 2021
}

\section{Summary}

Over the past decade, the Government of Tanzania has paid increasing attention to accountability in its nutrition policies. This has coincided with the introduction of truly innovative efforts to advance and monitor government action towards and accountability for nutrition at subnational level. A multisectoral nutrition scorecard (MNS) has been rolled out across all districts in the country, with quarterly updates on district performance. Moreover, a Nutrition Compact instrument was introduced to incentivise senior civil servants within regional and district administrations to advance efforts to promote nutrition. This paper explores how the government has used these initiatives to give accountability a particular form and meaning, pertinent to context. The paper analyses a series of policy documents and complements this analysis with field-based interviews with local officials across five regions. We find that the MNS and Compact are designed predominantly for internal purposes of government. This renders 'accountability tools' largely in the service of a centralised state, advancing vertical accountability. Such a narrow framing and design inhibits the potential of these instruments for galvanising social accountability, whereby citizens can hold public service providers and subnational government actors to account directly.

\section{Keywords}

Tanzania; accountability; nutrition; policy analysis.

\section{Authors}

Rishiraj Bhagawati is an independent consultant based in Guwahati, India, and is currently associated with a public policy firm in Pune, India. His research interests include qualitative social and political science, particularly research around health and nutrition equity. Rishiraj received a Master of Arts degree in Development Studies from the Institute of Development Studies (IDS) at the University of Sussex, UK. Prior to this, he worked as a journalist, covering health, science and national politics in India. He was affiliated with IDS as a research consultant at the time of writing this paper.

Dolf te Lintelo, PhD, is a Senior Research Fellow and leads the Cities Cluster at IDS, University of Sussex. Dolf's current research explores the relation between place-making, modalities of reception, the governance of informality and wellbeing in protracted urban displacement contexts. $\mathrm{He}$ is principal investigator on research council grants in urban Jordan, Lebanon, Turkey, India, the UK, Finland, and Norway. This entails leading transdisciplinary enquiry by academic and 
humanitarian practitioner teams from across architecture, urban design and planning, and social sciences. Dolf also works on methods and metrics evaluating government action on malnutrition.

John Msuya is an Associate Professor at Sokoine University of Agriculture (SUA), Tanzania. He is a versatile researcher-cum-educator and consultant, having spent a considerable amount of his three-decades career in research and university teaching. He holds a first degree in agriculture, a Master's in Human Nutrition, and a doctorate in Food Economics. He has served as a consultant and project advisor for a number of national and international institutions, including the Government of Tanzania, UNICEF, the Food and Agriculture Organization of the United Nations (FAO), the Canadian International Development Agency (CIDA), the United States Agency for International Development (USAID), IDS, Care International, AMREF, World Vision, Save the Children and PANITA (Partnership for Nutrition in Tanzania).

Tumaini Mikindo is Executive Director at PANITA, one of the largest civil society association networks, with more than 300 members across Tanzania. He has worked for reputable local and international organisations as well as bilateral donors, holding various positions, including both leadership and technical responsibilities. He represents PANITA in various multi-stakeholder nutrition and health forums globally. He has also served as Vice Chair of the Scaling Up Nutrition (SUN) Movement Executive Committee. He has extensive knowledge and experience in nutrition governance. 


\section{Contents}

Acknowledgements and acronyms

1. Introduction

2. Methodology

3. Vision on nutrition accountability expressed in policy documents

3.1 Common results, action plans, and multisectoral nutrition scorecard

3.2 The Compact

3.3 Nutrition data management across ministries and administrations

3.3.1 Coexistence of the MNS and the Compact in the MNIS

3.4 Towards what kind of nutrition accountability?

4. The MNS and the Compact at subnational level: empirical evidence from interviews

4.1 Takeaway 1: Many claimed familiarity with the two tools, but only at district level 32

4.2 Takeaway 2: The tools are having several positive outcomes

4.3 Takeaway 3: Local officials struggle to distinguish between the tools

4.4 Takeaway 4: Ties with community mobilisation and awareness

4.5 Takeaway 5: Data collected do not return to wards and villages

4.6 Takeaway 6: The missing link: accountability

5. Discussion and conclusion

Annexe 1: From the review of policy documents 
Annexe 1B: On the overlap of indicators between the MNS and the Compact

Annexe 2: From the field interviews

Annexe 2A: Questionnaire for the interviews

Annexe 2B: List of respondents

References

\section{Figures}

Figure 3.1 A timeline showing the publication of all nutrition reports

Figure 3.2 Components of the Multisectoral Nutrition Information System

Figure 3.3 The overlap in indicators between the MNS and the Compact

Figure 4.1 Distribution by administrative level of 83 respondents who claimed to be unfamiliar with the MNS and the Compact

Figure A1 Questionnaire used in the field interviews

\section{Tables}

Table 3.1 Relationship between the National Multisectoral Nutrition Action Plan key result areas and the Common Results, Resources and Accountability Framework outcomes

Table A1 Excerpts from policy documents regarding implementation of the Compact

Table A2 Similarities in indicator focus in the MNS and the Compact 


\section{Acknowledgements}

This paper has been produced thanks to Irish Aid funding, from the Government of Ireland.

The opinions expressed here belong to the authors, and do not necessarily reflect those of Irish Aid or the Institute of Development Studies.

\section{Acronyms}

$\begin{array}{ll}\text { CRRAF } & \text { Common Results, Resources and Accountability Framework } \\ \text { CSO } & \begin{array}{l}\text { civil society organisation } \\ \text { district steering committee on nutrition }\end{array} \\ \text { DSCN } & \text { Integrated Management of Acute Malnutrition } \\ \text { IMAM } & \text { Integrated Monitoring and Evaluation System } \\ \text { iMES } & \text { Joint Multisectoral Nutrition Review } \\ \text { JMNR } & \text { local government authority } \\ \text { LGA } & \text { Multisectoral Nutrition Information System } \\ \text { MNIS } & \text { Multisectoral Nutrition Scorecard } \\ \text { MNS } & \text { National Multisectoral Nutrition Action Plan } \\ \text { NMNAP } & \text { National Nutrition Strategy } \\ \text { NNS } & \text { Partnership for Nutrition in Tanzania } \\ \text { PANITA } & \text { President's Office - Regional Administration and Local } \\ \text { PO-RALG } & \text { Government } \\ \text { RS } & \text { regional secretariat } \\ \text { SUN } & \text { Scaling Up Nutrition } \\ \text { TFNC } & \text { Tanzania Food and Nutrition Centre } \\ \text { UNICEF } & \text { United Nations Children's Fund }\end{array}$




\section{Introduction}

Nutrition in Tanzania remains a critical issue. Over the past decade, progress on key indicators such as stunting has been good, but needs to be accelerated, as overall levels remain high: nearly one in three children under five remain stunted 1 (Government of Tanzania 2019a). Conversely, progress made in the 2000s towards reducing the high incidence of maternal anaemia has seen some recent reverses, and a growing share of the population is overweight and obese (Headey et al. 2019).

In the past few years, the Government of Tanzania has expended a significant amount of political commitment and energy directed at governance innovations with a substantial promise to accelerate nutrition improvements. In many ways, Tanzania appears to be a key contemporary innovator regarding nutrition governance; and it is no coincidence that other African governments, such as Kenya, are actively seeking to learn from Tanzania's experience. ${ }^{2}$ Highly coordinated multisectoral governance mechanisms have been initiated at national, regional, and district levels. Policy and programme delivery mechanisms at the subnational level have been gradually strengthened and vertical coordination fostered. The government has: put in place dedicated nutrition officers in all districts; created a separate budget line for nutrition across all layers of government to facilitate greater spending transparency; institutionalised annual multisectoral strategic policy review processes; and initiated performance contracts making subnational-level officials personally more accountable for progress on nutrition in their territories.

Furthermore, Tanzania has introduced innovative scorecard instruments that seek to provide highly organised, regular data updates on nutrition-specific and nutrition-sensitive activities, outputs, and outcomes at subnational level. Accordingly, the government has also put in place (since 2015 and with the support of UNICEF) a multisectoral nutrition scorecard (MNS) that aims to strengthen accountability by measuring efforts to improve nutrition outcomes at the district level. The MNS, which has been rolled out across all 125 districts, is designed to work alongside an overarching Common Results, Resources and Accountability Framework (CRRAF), which was developed around the same time. Moreover, in 2018, the Tanzanian Minister of State in the President's Office - Regional Administration and Local Government (PO-RALG), on behalf of then vice president (and now president) Samia Suluhu Hassan, signed a Nutrition Compact with all 26 regional commissioners to introduce a new approach to

1 On another key indicator - the prevalence of wasting among children under five - the country saw a decrease from 3.8 per cent in 2014 to 3.5 per cent in 2018 (Government of Tanzania 2019a: 98).

2 Tanzanian policy consultant (pers. comm. 2019). 
oversee the implementation of nutrition interventions at subnational level. The Nutrition Compact (henceforth referred to as the Compact) is a contract that measures the performance of regions on a set of nutrition-specific indicators and disbursement of nutrition-related funds, using a scorecard approach similar to the MNS. As of 2019, the Compact was further cascaded down to district level, covering all 184 councils.

The global academic literature on scorecards used at subnational levels provides some evidence that they can have positive effects on accountability, by strengthening communication between stakeholders, increasing citizen engagement and advocacy efforts, and empowering citizens, service providers, and public officials to hold decision makers to account (Hilber et al. 2016; Blake et al. 2016; ten Hoope-Bender et al. 2016). Whether this may also be the case for nutrition in Tanzania is not currently clear, as information and evidence on policymakers' vision on accountability and the actual functioning of the scorecards is dispersed, and access constrained. Moreover, in the past few years, under the presidency of the late John Magufuli, Tanzania witnessed a clear descent into authoritarianism, with the space for civil society and academic critique of government being significantly curtailed.

This report attempts to piece together policymakers' visions for the MNS and the Compact at subnational level, and how these instruments are being used, to assess their implications for nutrition accountability, and to inform a wide range of actions by local, national, and international stakeholders.

To that end, the report addresses three research questions:

1. Why did the CRRAF, MNS and Compact emerge, what are their respective visions on nutrition accountability, and how is this expressed in the design of the scorecards and accompanying monitoring mechanisms?

2. What is the current access to and use of the MNS and Compact at the subnational level in Tanzania?

3. How are communities, civil society and development partners employing the MNS and Compact to help foster nutrition accountability?

Our analysis seeks to elucidate the relations between the MNS and the Compact, given the not inconsiderable current confusion about this, as a prospective first step to future analyses of how these instruments reshape subnational contestations for nutrition resources, processes, and outcomes between key stakeholders such as communities, officials, elected political leaders, civil society groups, and development partners. 


\section{Methodology}

This study commenced in 2020, and as a result of the global Covid-19 pandemic, partners from the United Kingdom (UK) were unable to visit Tanzania to jointly conduct fieldwork, interviews, and workshops with Tanzanian partners. Consequently, contributions pivoted towards a distanced, more desk-based approach.

In the initial stages of the study, efforts were made to obtain minutes of meetings of the district steering committee on nutrition (DSCN). Partners had hoped to learn about the vision expressed on nutrition accountability in nutrition meetings at lower levels of government, and the extent to which tools such as the MNS and Compact are employed at district, ward, and village levels. With the support of the Tanzania Food and Nutrition Centre (TFNC), we obtained a set of DSCN meeting minutes, and began translating these from Kiswahili into English. It quickly became clear that the transcripts of the minutes were of little use to our research. The minutes largely consisted of attendance records, with some mention of agenda items. If there were any substantive discussions by committee members about the MNS or the Compact scorecards and their data, none were recorded, apparently reflecting prevailing minuting practice in local government meetings.

Forced to abandon our initial approach, we turned to two research methods that together helped us answer the research questions on nutrition accountability in Tanzania. These were: (1) a detailed look into policy using a scoping study of national nutrition documents; and (2) interactions with key stakeholders concerned with nutrition at lower government levels using a series of field interviews. This was made possible, as Tanzanian partners felt able to undertake fieldwork in November and December 2020.

To answer the first research question on the vision, evolution, and purpose of the accountability mechanisms in Tanzanian nutrition policies, this report analyses several national nutrition policies and policy evaluation reports published since 2010. These documents include the following.

- National Nutrition Strategy (NNS) 2011-12 to 2015-16: Tanzania's principal national approach for nutrition implementation that was used in the five-year period between 2011 and 2016.

- National Multisectoral Nutrition Action Plan (NMNAP) 2016-21: Tanzania's nutrition strategy that replaced the NNS for the subsequent five years.

- NMNAP Mid-Term Review 2019: Report on the progress of NMNAP's objectives, published three years after it began implementation. 
- Joint Multisectoral Nutrition Reviews (JMNRs): Annual reviews conducted by the Prime Minister's Office to review operational progress, challenges, and opportunities, which also recommends ways forward in nutrition matters. These reviews began in 2014 and were conducted every year until 2019. This report includes information from all six JMNRs published so far.

- Evaluation meeting reports on the implementation of the Nutrition Compact: These biannual and annual reports summarise the evaluation meetings held by PO-RALG to oversee the implementation of the Compact. We have analysed all Compact evaluation reports except the first one (published in August 2018), which was unobtainable.

We also benefited from being able to review several slide decks presented by government officials, and were able to draw on insights of local partners at the Sokoine University of Agriculture (John Msuya) and from Tumaini Mikindo, Chief Executive Officer (CEO) of the Partnership on Nutrition in Tanzania (PANITA), a federation of local civil society organisations working on nutrition. To facilitate fieldwork on the second research question, Professor Msuya consulted senior officials in the PO-RALG who helped to secure government permission for the study, and facilitated access to officials in district councils. Further, in order to clarify matters regarding details of some policy implementation, we sought and received inputs from two key informants responsible for the data collection systems at TFNC and PO-RALG.

For the second research question, on how the MNS and Compact are being used at lower levels of government, we interviewed 204 officials in five districts located in five regions: Kigoma (in Kigoma region); Kishapu (in Shinyanga region); Mbeya (in Mbeya region); Misungwi (in Mwanza region); and Morogoro (in Morogoro region). These interviews were conducted by a team of research assistants with a nutrition background from Sokoine University of Agriculture during November and December 2020. Respondents included members of the development committees at three administrative levels: the district, ward, and village. At the district level, respondents represented at least half the district committee; although a majority were government officials, we also interviewed other committee members such as representatives of religious groups and nongovernmental organisations (NGOs). The government has decided not to create new multi-stakeholder platforms below the district level, instead promoting nutrition dialogue within existing ward development committees and village councils, as these comprise members from government, civil society groups, faith-based organisations, and the private sector. Within each selected district, two wards were chosen - one close to the district council headquarters and one further away. Within each selected ward, two villages were chosen, and their development committee members selected for interview.

The five regions were selected to provide a general picture of the country, as nutrition statuses vary significantly across each region. There were also other 
compelling reasons for selecting particular district councils within each region. For instance, Morogoro and Kigoma were involved in earlier fieldwork on subnational nutrition scorecards by team members (te Lintelo 2019), while Mbeya - unlike the former two regions - has been receiving substantial nutrition support from UNICEF for a number of years. Upon request of the funder, we included Misungwi (which has received nutrition support from Irish Aid for a few years now), while Kishapu was specifically recommended by PO-RALG because it has the worst performance on nutrition within the Lake Zone.

At the time of setting the structured interview questionnaire, both the MNS and the Compact appeared to serve a synonymous purpose, and detailed differences in their mandate or scope were neither published nor fully clear to the research team. As initial consultations with nutrition professionals and government officials engaged in nutrition policy and planning at the national level in Tanzania also did not generate full clarity, we framed interview questions broadly and asked respondents to reflect on the MNS and/or the Compact.

Importantly, field research showed that very few respondents were able to distinguish between the MNS and the Compact. Indeed, it took an in-depth analysis of the nutrition policy documents to identify some of the finer differences between the two instruments (elaborated in section 3), yet even so, not to a fully satisfactory standard.

The research team also encountered some difficulties during the process of conducting the interviews. In a couple of districts, interviewers interacted with government officials immediately after ward or village council meetings, since that allowed access to a wider set of respondents. In such cases, it was possible that the respondents, who were sitting close to one another, overheard answers given by their colleagues in the council, resulting in our recording similar or identical sets of responses for multiple questions in those instances. There were also some differences in how respondents from the different districts interpreted some of the questions, possibly reflecting the diverse composition of the team of research assistants, despite careful prior instruction by the local team lead. As expected, the number and kind of respondents interviewed in each district varied slightly depending on local availability. Accordingly, a generally similar (but not fully uniform) approach was taken towards conducting the interviews across all sites. Nevertheless, given the overall trends observed from each district after our analysis, we are confident in the validity of the data for addressing the aim and scope of this study.

The complete set of questions posed in the field interviews is available in Annexe $2 \mathrm{~A}$. The responses to these questions were interpreted through a thematic coding process in the qualitative data coding software NVivo. Once the broad themes had emerged, they were jointly analysed, and the takeaways of this analysis are presented in section 4. 


\section{Vision on nutrition accountability expressed in policy documents}

This section lays out the Tanzanian government's vision on nutrition accountability expressed in national policies and reports over the previous decade. To that end, we review two five-year nutrition strategies from 2011 to 2021, annual nutrition reviews from 2014 to 2019, and other relevant materials to analyse the genesis and evolution of three specific frameworks and tools related to nutrition accountability. We then discuss the nature of this accountability as observed in these documents, and then finally touch on the role of development and non-governmental partners in this space in Tanzania.

Before we begin, and to set our discussion of nutrition policy documents in context, Figure 3.1 provides a timeline of policy decisions and key documents reviewed to distil the relations between the CRRAF, the MNS, and the Compact.

\subsection{Common results, action plans, and multisectoral nutrition scorecard}

Recognition of the need to build accountability mechanisms in nutrition came about through a gradual process over the previous decade. The National Nutrition Strategy (NNS), which outlined Tanzania's ambitions to implement nutrition-related programmes from 2011-12 to 2015-16, mentioned 'enhancing public accountability' as a goal that could be achieved through effective research, monitoring, and evaluation activities. There was little explanation of what the term 'accountability' meant in the context of nutrition governance, but the NNS gave a preview of what would turn out to be an important component of nutrition reviews and policies published in subsequent years. Stimulated by the emergence of the global Scaling Up Nutrition (SUN) movement, in 2013 President Jakaya Kikwete ${ }^{3}$ declared Tanzania an 'early riser country', to join its international SUN lead group, and to issue a Presidential Call for Action on Nutrition (Government of Tanzania 2013). The SUN movement, comprising all main development partners, ${ }^{4}$ provided substantial technical and financial assistance to the Government of Tanzania in the following decade, to underline

3 Former Tanzanian president Jakaya Kikwete is still a member of the SUN lead group. However, he works there in an individual capacity, and not as a country representative.

4 While the NNS in 2011 recognised the financial and technical support of only one such partner, UNICEF, the list steadily grew in acknowledgement sections of all subsequent government publications on nutrition throughout the decade. Notably, this increase in both financial and non-financial assistance in nutrition programmes from non-state actors coincided with a growing need to hold the state and stakeholders internally accountable for results and resources. JMNR 2018 recognised financial help from at least ten development organisations. 
the necessity of greater multisectoral coordination within government and with the non-governmental and private sectors. Its discourse of scaling up nutrition is significantly reflected in the NMNAP, which is 60 per cent funded by development partners, with government providing 30 per cent and the private sector 10 per cent (Government of Tanzania 2016a: 6).

\section{Figure 3.1 A timeline showing the publication of all nutrition reports}

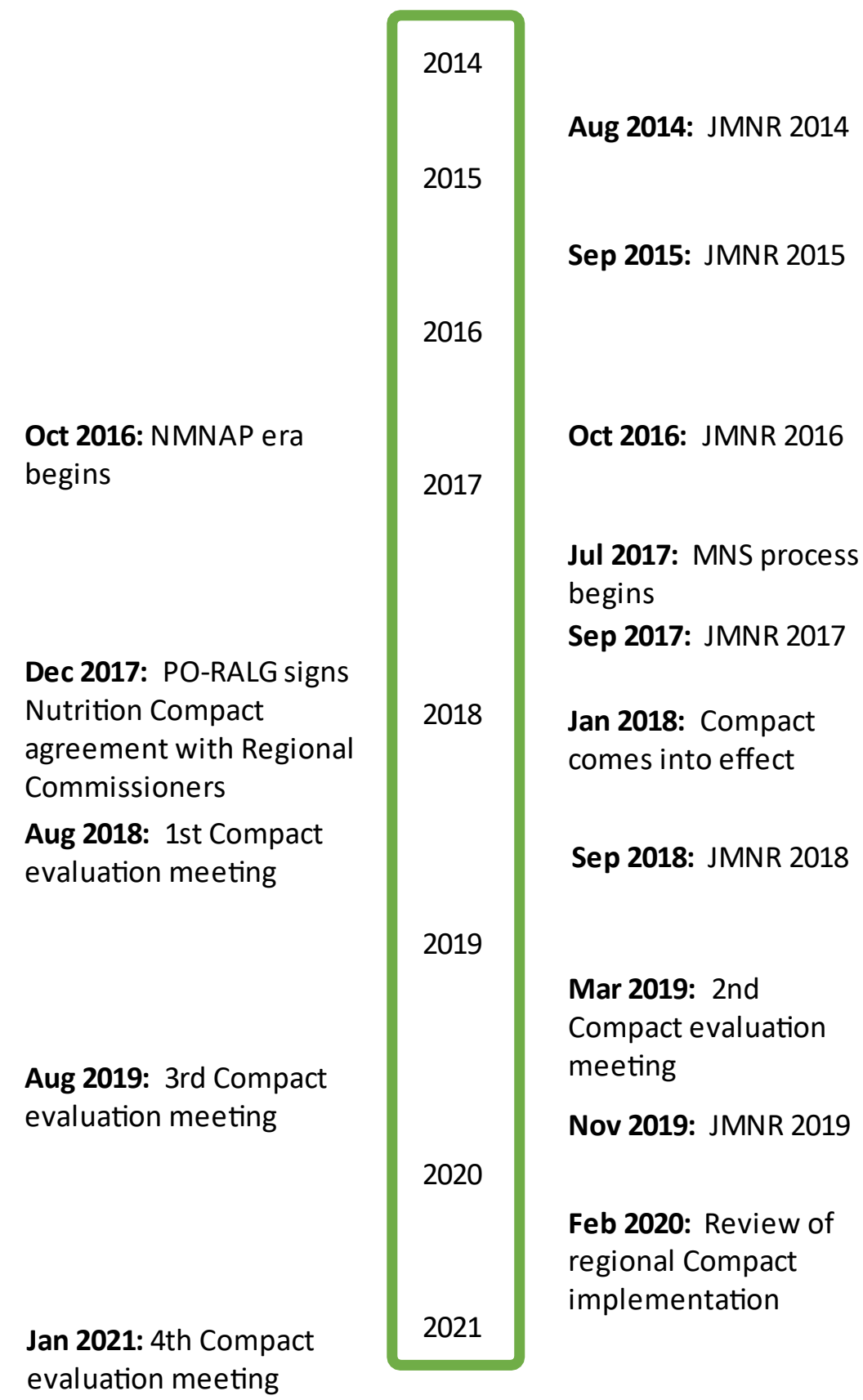


With this new impetus towards horizontal and vertical coordination, the final years of the NNS saw the publication of Joint Multisectoral Nutrition Reviews (JMNRs) under the aegis of the Prime Minister's Office. These annual reviews entailed a large gathering of stakeholders in Dar es Salaam (and later in Dodoma) from across administrative sectors and layers, as well as development partners and civil society groups, to jointly assess progress towards nutrition outcomes. The first JMNR was published in 2014, with the objective of reviewing the first three years of the NNS. One of its main recommendations was to develop a Common Results, Resources and Accountability Framework (CRRAF) to track the progress of the NNS. The lack of such a framework, the document notes, 'makes it difficult to monitor and evaluate on the basis of results' (Government of Tanzania 2014: 14). Although introduced primarily to align the goals and resources of the government's nutrition-related schemes, CRRAF was proposed in JMNR 2014 as a solution to challenges such as the lack of a monitoring and evaluation framework (ibid.). To the best of our knowledge, this was the first time such a framework had been proposed (and subsequently implemented) in national nutrition policy globally.

The Tanzania Food and Nutrition Centre (TFNC) was tasked with developing the CRRAF by mid-2015. Although group discussions in JMNR 2014 recommended that the CRRAF include 'outcome and process indicators, the estimated resources (human and financial) to achieve agreed results and the time frame', the actual details of the framework were not made public until a couple of years later (Government of Tanzania 2014: 30). Instead, CRRAF continued to feature in the list of recommendations of the next annual review, JMNR 2015, where the framework was shown to be an important component of the upcoming National Multisectoral Nutrition Action Plan (NMNAP) - the central nutrition policy to inherit the baton from the NNS for the period 2015-16 until 2020-21. The Prime Minister's Office, in addition to the TFNC, was now to oversee the development of the CRRAF (Government of Tanzania 2015: 9).

Interestingly, although the CRRAF is seen as a significant part of the imminent NMNAP in JMNR 2015, it was yet to be written about as a definite tool or even as an acronym, unlike how the JMNRs of subsequent years talk about the CRRAF. This suggests that there was little progress on developing the framework at this stage. JMNR 2015 introduced another tool that would later add to Tanzania's mix of nutrition-specific accountability mechanisms - the multisectoral nutrition scorecard (MNS). Even with little detail on the structure, scope, and use of the scorecard in JMNR 2015, two similarities emerged between the CRRAF and the MNS: (1) both were to be included in the upcoming NMNAP strategy; and (2) they were to be developed together by the Prime Minister's Office and the TFNC (ibid.). 
Nutrition Accountability through Sub-National Scorecards in Tanzania - Policy Innovations and Field Realities

The picture gets a lot clearer with the publication of JMNR 2016. Taking place around the same time that the NMNAP was drafted, the TFNC clarified that 'while the CRRAF combines results, resources and accountability from all stakeholders to achieve synergies for the One Desired NMNAP Outcome, the scorecard is the tool for monitoring the outputs of the NMNAP' (Government of Tanzania 2016b: 22). The CRRAF and the MNS are designed to be the primary reference tools of the government during meetings of the High-Level Steering Committee on Nutrition, the Multisectoral Nutrition Technical Working Group (MNTWG), and regional and district steering committees on nutrition, as the TFNC explained (Government of Tanzania 2016b: 24). Both the High-Level Steering Committee and the Technical Working Group featured substantial participation by development partners.

The CRRAF has seven outcomes, each of which includes several outputs, which in turn delegate duties to departments and organisations to achieve the targets, allocate budgets, and define indicators to measure progress. These seven outcomes correspond to the seven 'key result areas' of the NMNAP (see Table 3.1).

\section{Table 3.1 Relationship between the National Multisectoral Nutrition Action Plan key result areas and the Common Results, Resources and Accountability Framework outcomes}

\begin{tabular}{|c|c|c|c|}
\hline \multicolumn{2}{|c|}{ NMNAP } & \multicolumn{2}{|l|}{ CRRAF } \\
\hline & $\begin{array}{l}\text { Key result area } \\
\text { (KRA) }\end{array}$ & & Outcome \\
\hline $\begin{array}{l}\text { KRA } \\
1\end{array}$ & $\begin{array}{l}\text { Scaling up maternal, } \\
\text { infant, young child } \\
\text { and adolescent } \\
\text { nutrition }\end{array}$ & $\begin{array}{l}\text { Outcome } \\
1\end{array}$ & $\begin{array}{l}\text { Increased proportion of adolescents, } \\
\text { pregnant women and mothers / } \\
\text { caregivers of children under two } \\
\text { years who practice optimal } \\
\text { maternal, infant and young child } \\
\text { nutrition behaviours }\end{array}$ \\
\hline $\begin{array}{l}\text { KRA } \\
2\end{array}$ & $\begin{array}{l}\text { Scaling up prevention } \\
\text { and control of } \\
\text { micronutrient } \\
\text { deficiencies }\end{array}$ & $\begin{array}{l}\text { Outcome } \\
2\end{array}$ & $\begin{array}{l}\text { Children, adolescents and women of } \\
\text { childbearing age consume adequate } \\
\text { micronutrients }\end{array}$ \\
\hline $\begin{array}{l}\text { KRA } \\
3\end{array}$ & $\begin{array}{l}\text { Scaling up integrated } \\
\text { management of acute } \\
\text { malnutrition }\end{array}$ & $\begin{array}{l}\text { Outcome } \\
3\end{array}$ & $\begin{array}{l}\text { Increased coverage of integrated } \\
\text { management of severe and } \\
\text { moderate acute malnutrition }\end{array}$ \\
\hline
\end{tabular}




\section{Table 3.1 (cont'd.)}

\begin{tabular}{|c|c|c|c|}
\hline \multicolumn{2}{|c|}{ NMNAP } & \multicolumn{2}{|l|}{ CRRAF } \\
\hline & $\begin{array}{l}\text { Key result area } \\
\text { (KRA) }\end{array}$ & & Outcome \\
\hline $\begin{array}{l}\text { KRA } \\
4\end{array}$ & $\begin{array}{l}\text { Scaling up prevention } \\
\text { and management of } \\
\text { diet-related non- } \\
\text { communicable } \\
\text { diseases }\end{array}$ & $\begin{array}{l}\text { Outcome } \\
4\end{array}$ & $\begin{array}{l}\text { Communities in Tanzania are } \\
\text { physically active and eat healthy }\end{array}$ \\
\hline $\begin{array}{l}\text { KRA } \\
5\end{array}$ & $\begin{array}{l}\text { Integration of } \\
\text { multisectoral nutrition- } \\
\text { sensitive } \\
\text { interventions }\end{array}$ & $\begin{array}{l}\text { Outcome } \\
5\end{array}$ & $\begin{array}{l}\text { Line sectors, private sector and civil } \\
\text { society organisations scale up } \\
\text { nutrition-sensitive interventions to } \\
\text { reach all communities to improve } \\
\text { nutrition }\end{array}$ \\
\hline $\begin{array}{l}\text { KRA } \\
6\end{array}$ & $\begin{array}{l}\text { Improving } \\
\text { multisectoral nutrition } \\
\text { governance }\end{array}$ & $\begin{array}{l}\text { Outcome } \\
6\end{array}$ & $\begin{array}{l}\text { Efficient and effective nutrition } \\
\text { governance }\end{array}$ \\
\hline $\begin{array}{l}\text { KRA } \\
7\end{array}$ & $\begin{array}{l}\text { Establishing a } \\
\text { multisectoral nutrition } \\
\text { information system }\end{array}$ & $\begin{array}{l}\text { Outcome } \\
7\end{array}$ & $\begin{array}{l}\text { Quality nutrition-related information } \\
\text { is accessible and used to allow } \\
\text { government and partners to make } \\
\text { timely and effective evidence- } \\
\text { informed decisions }\end{array}$ \\
\hline
\end{tabular}

Source: Authors' own.

The CRRAF was hence defined as a framework to bring in - and facilitate the synergy between - several actors and sectors working towards a set of common results. It outlined a pathway including outputs, outcomes, and impacts deemed necessary to achieve those common results. The framework also explicitly lists the accountable institutions - which include government ministries, departments, agencies, NGOs, and private sector bodies - and the resources needed to achieve each output.

Moreover, the framework facilitates regular tracking of progress using predefined targets for disbursement of funds and achievement of the outputs, outcomes, and impacts. One attribute of the CRRAF emphasised by JMNR 2016 is that the tool does not require additional funding or resources for its implementation because it merely makes a nutrition-focused framework out of pre-existing targets for various sectors (Government of Tanzania 2016b: 23). Indicators, resources, and funding requirements mentioned in the CRRAF's objectives are borrowed from the existing Five-Year Development Plan II and sectoral plans, which also makes it simpler to track progress. Even though JMNR 2016 does not go into the detailed structure of the framework, it confirms that the CRRAF is primarily about fostering coordination across multiple nutrition-specific and nutrition-sensitive sectors. It also brings to the fore what each contributor 
offers, while seeking to advance mutual transparency and horizontal accountability between key actors.

JMNR 2016 describes the MNS as a web-based tool for quarterly tracking of performance on indicators and targets associated with the NMNAP (Government of Tanzania 2016b: 23). The MNS adopts a traffic-light system wherein indicator performances of districts and subsequently regions are measured against predefined threshold values. The scorecard is based on information provided by 'nutrition officers in the councils and regions, in collaboration with officers from nutrition sensitive sectors and Health Management Information System (HMIS) coordinators', who fill in output-level indicators, while outcome and impact indicators of the NMNAP are informed by nationwide surveys and studies (Government of Tanzania 2016b: 23).

The MNS too has been defined as an accountability tool, which will regularly feed into the CRRAF to allow for tracking of nutrition interventions and aid decision-making (Government of Tanzania 2016b: 24). Initiated by the TFNC and supported by UNICEF, the intended uses of the MNS (according to the TFNC's inputs in JMNR 2016) are limited to helping the government track the impact of the NMNAP, helping nutrition officers prioritise actions based on evidence, and facilitating decision-making in the nutrition sector.

In summary, JMNR 2016 shows that the CRRAF and the MNS are 'two powerful tools' within the NMNAP that have been designed to aid the implementation of nutrition interventions in a few specific ways (Government of Tanzania 2016b: 24). They: (1) bring relevant sectors together around concrete interventions, results, and funding commitments; (2) provide evidence for decision-making and action, including budget allocation; and (3) generate accountability towards the achievement of results and compliance with financial commitments (i.e. budgetary allocations) (ibid.). However, they essentially differ in purpose and scale: while the CRRAF coordinates inputs or what goes in (i.e. aligning sectoral goals and resources to aim for common results and setting stakeholders responsible for action at the national level), the MNS monitors outputs or what comes out (tracking progress of the NMNAP on all those output areas at district levels, which is then aggregated at the regional and national levels). The CRRAF therefore presents a framework that offers greater mutual transparency in terms of the type and level of contributions made by different sectors (from agriculture to social protection, to health and nutrition), and thus offers a measure of 'horizontal' accountability at the national level. It demands few sacrifices from, but fosters cohesion in, the joint effort of contributing parties towards better nutrition in Tanzania. In contrast, the MNS is a centralising mechanism that renders more visible to higher authorities the nutrition-related actions and failures of lower administrative authorities. While the 'vertical' structure of accountability relations are not altered, the MNS changes this relation by imposing on 
subnational authorities the requirement to produce, and be accountable for, quarterly data on nutrition efforts and outcomes, in the light of policy goals.

\subsection{The Compact}

In August 2017, during the National Food Fortification Summit, then vice president (and now president) Samia Suluhu Hassan gave directives to constitute a nutrition performance agreement with all 26 regional commissioners of the Tanzania mainland to oversee the implementation of nutrition activities in the regions (Government of Tanzania 2019b: 3). Three months later, the minister of state for PO-RALG, on behalf of the vice president, signed the Nutrition Performance Compact Agreement for Nutrition Intervention Implementation with all the regional commissioners. The Compact agreement came into effect in January 2018.

Although the original Compact is not publicly available for inclusion in this study, we draw on the reports of evaluation meetings that have been taking place since 2018.

Much like the CRRAF and MNS, formulation of a nutrition monitoring mechanism at the level of local government authorities (LGAs) and regional secretariats (RSs) was hinted at before the Compact actually came into being. Among the recommendations of JMNR 2016, PO-RALG was given the task to 'review and harmonise supervision tools for multisectoral nutrition activities' for RSs and LGAs by the next year (Government of Tanzania 2016b: 7). In the subsequent review (JMNR 2017), the deputy minister of PO-RALG reiterated his department's commitment towards NMNAP implementation, and revealed a focus on coordinating nutrition-related actions taken by regions and councils. He said that a 'performance contract' with regional commissioners was being drafted on the instructions of then vice president Hassan to ensure regular follow-ups, monitoring and management of nutrition interventions in areas under PO-RALG's jurisdiction (Government of Tanzania 2017: 18).

JMNR 2018 is the first annual review to mention the Compact by name. In an update on the implementation status of JMNR 2017's recommendations, the Compact is shown to be a response to the third recommendation, which read, 'To strengthen incentive mechanisms for LGA and RS to enhance accountability in domestic resources utilisation and performance - Lead by PO-RALG'

(Government of Tanzania 2018: 20). The review's update to this recommendation informs that the Compact was introduced as a contract between PO-RALG and regional commissioners, which specified 'indicators to which all local and regional authorities are accountable' (ibid.).

The Compact thus offers an important new mechanism to allow central government to hold lower levels of government (under the PO-RALG's 
jurisdiction) to account for effective use of domestic resources to meet nutrition spending (and, indirectly, output, outcome and impact) targets set by national policies. This understanding is reflected in several instances within JMNRs 2018 and 2019, including a statement by the UNICEF deputy country representative, who applauded the signing of the Compact as a means 'to oversee implementation of the NMNAP in every region, in terms of funds disbursed for nutrition interventions and results achieved' (Government of Tanzania 2018: 81).

The Compact's focus has much in common with the NMNAP and its tools (evident from a comparison of indicators, as shown later in this report), but its audience and method to achieve those targets are unique. In the Tanzanian system of public administration, presidential appointees - the regional and district commissioners - represent the president locally. They are often the most powerful actors at the local level, and their voice carries greater weight than that of the most senior bureaucrats, the district executive directors. The Compact, as an experimental initiative, thus also presents a mechanism that strengthens centralised administrative oversight and control by the vice president and president over these appointees. Since the Compact is a PO-RALG tool, it addresses the section of government departments that are under PO-RALG's jurisdiction: regional administration and local government bodies. The Compact operates entirely through these channels to achieve its objectives, and this operational structure is evident in the summaries of the Compact evaluation meeting reports. For instance, in the second evaluation meeting of the Compact, the minister of state for PO-RALG challenged the 31 councils that did not disburse funds for the implementation of nutrition activities between July and December 2018, asking the regional commissioners heading those councils for explanations (Government of Tanzania 2019c: 6). On the other hand, regions are also congratulated for good performance, with Kilimanjaro, Njombe, and Iringa recognised for 'outstanding performance in implementation of Nutrition Compact' in the third evaluation meeting (Government of Tanzania 2019b: 1719). Annexe $1 \mathrm{~A}$ provides further examples of this. The Compact, through its generation of competitive dynamics between regions and districts, thus appears to create incentives to demonstrate progress in action on nutrition. Although there is a lack of evidence on whether such competition drives accelerated reduction of malnutrition, it is clear that the Compact seeks to support implementation of the national policy at the subnational level.

The Compact may, however, also be viewed as strengthening political oversight and control by the (vice) presidency. The president is also the chief of the Chama Cha Mapinduzi (CCM) political party, which has reigned Tanzania since post-independence in 1964. Regional and district commissioners are typically party loyalists, some of whom will harbour political career aspirations (Hoffman 2013). The Compact thus offers not only an administrative instrument but also a 
party political tool that can be used to shore up intra-party coalitions and loyalty to its local, regional, and national party leadership.

Although the Compact had not been developed when the NMNAP commenced as Tanzania's primary nutrition policy in 2016, it has since evolved to be a key accountability tool under the NMNAP. By 2019, NMNAP's Mid-Term Review noted that all 25 regions and 184 district councils of Tanzania had implemented the Compact, and the focus was now on ensuring ward leaders' oversight of its implementation at ward levels (Government of Tanzania 2019d: 59). The review, conducted by the Prime Minister's Office, praised the Compact's progress, and acknowledged its role in the 'significant progress made in increasing ownership, commitment and accountability of regional and district commissioners to nutrition and specifically to NMNAP implementation' (ibid.).

Accordingly, the 2019 Mid-Term Review recognised the role of the Compact in a range of NMNAP elements, including: (1) aligning efforts at regional and district levels to national nutrition objectives, thereby elevating awareness and understanding of nutrition actions among local leaders; (2) as a key component of NMNAP's sixth ${ }^{\text {th }}$ key result area, which dealt with establishing efficient and effective nutrition governance; (3) as a key component of NMNAP's seventh ${ }^{\text {th }}$ key result area, where it appeared as a tool for monitoring and evaluation; (4) as a part of 'advocacy and social mobilisation', which is one of NMNAP's ten strategies to achieve its objectives; and (5) as NMNAP's primary tool to track and improve budgetary allowances and disbursement of nutrition funds at regional and district levels.

Along with other existing mechanisms, the Compact is now an important component of the revised CRRAF (Government of Tanzania 2019d: 91-120); it repeatedly appears as a source of information for outputs under CRRAF outcomes 1, 6, and 7. The Compact is also listed in the Mid-Term Review among the evidence-based mechanisms to track overall and continuous progress of the NMNAP, along with JMNRs, bottleneck analyses, ${ }^{5}$ the MNS, annual workplans, and development of the Multisectoral Nutrition Information System (MNIS) (Government of Tanzania 2019d: 62). Given the extent of the Compact's applications, the review recommends an increase in its scope in the second phase of NMNAP implementation, post-2021.

5 Bottleneck analyses have been carried out in multiple stages to look at areas within the processes of delivery of nutrition interventions that inhibit the workflow. For instance, in 2015-16, bottleneck analyses were conducted at LGA level to 'systematically assess the main determinants of effective coverage of the selected nutrition interventions in order to design evidence-based strategies for scaling-up' (Government of Tanzania 2016b: 12). 


\subsection{Nutrition data management across ministries and administrations}

The NMNAP document of 2016 laid the foundation for the establishment of the MNIS, the objective of which was to 'ensure better quality and more timely collection and dissemination of outcomes (and programme performance) data for evidence informed advocacy, communication and adaptive management of the NMNAP' (Government of Tanzania 2016a: 83). The MNIS was designed to centrally collate nutrition-related data from sectoral information systems already in use by different ministries. For the first time, it sought to integrate information systems that regularly collected data on nutrition lodged in a range of ministries, such as the Food Security Information System, the Health Management Information System, the Education Information Management System, and the Tanzania Commission for AIDS information system, among others.

The MNIS drew inspiration from other efforts to systematically collate data from a range of sources, including large-scale national surveys such as the Tanzania Demographic and Health Survey, the STEPS ${ }^{6}$ survey, the Nutrition Public Expenditure Review, and the National Nutrition Survey. Nutrition survey data were typically generated every 4-5 years, making them more useful for longterm policy and strategy development than for tracking operational progress or assessing bottlenecks in the delivery of interventions (Government of Tanzania 2016a: 100).

Another advantage of the MNIS was that it would bring together data from all administrative levels. National nutrition surveys and reports were designed to be 'statistically representative only at the regional and national levels' and thus did not contain data specific to district, council, ward, and village levels. The NMNAP also recommended that the TFNC be provided with resources and training to function as the single institution to streamline the process of establishing the MNIS, and set out its vision as follows:

The full potential of a nutrition information system can be harnessed if the system covers all administrative levels, from national to council and community levels; if the data can be analysed quickly and used at the point of collection and if the timeliness and quality of the information collected is robust.

(Government of Tanzania 2016a: 100)

6 The STEPwise Approach to NCD Risk Factor Surveillance (STEPS) is 'a simple, standardized method for collecting, analysing and disseminating data on key NCD risk factors in countries' (WHO n.d.). NCD, here, refers to noncommunicable diseases. 
The MNS and the Compact, along with other nutrition surveys and information systems, thus contribute subnational level data to the new MNIS, from districts and regions and at short time intervals (quarterly and biannually).

Figure 3.2 shows how the MNIS functions to collate data in a single platform. This schematic diagram is an indicative illustration of how the MNIS is structured; it may not comprehensively represent all of its components.

\section{Figure 3.2 Components of the Multisectoral Nutrition Information System}

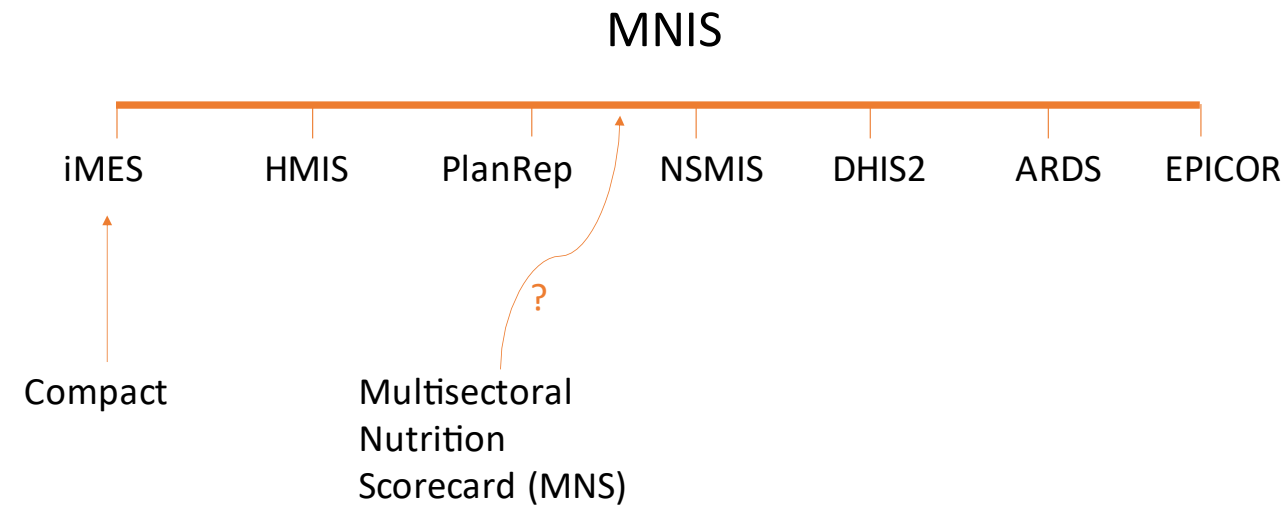

Source: Authors' own.

Note: PlanRep (Planning and Reporting System), NSMIS (National Sanitation Management Information System) DHIS2 (District Health Information System 2), ARDS (Agricultural Routine Data System).

When the Compact began in 2018, the MNIS was still being developed and was not yet functional. Consequently, PO-RALG (which oversees the implementation of the Compact) adopted a web-based system, called the Integrated Monitoring and Evaluation System (iMES), to generate Compact scorecards. As explained in the third evaluation meeting report:

The integration of Nutrition Compact into iMES was to echo the need for a simplified and systemised way to conduct Compact performance analysis. This system reduces manual work during data analysis and it also allows Regions and Councils to produce their own scorecard based on their performances.

(Government of Tanzania 2019b: 4) 
Once the MNIS is fully functional, the iMES containing Compact scorecards will feed nutrition information directly into the MNIS - a process that was set to begin in mid-2021 but had not yet begun by the time this report was written (November 2021).

Similarly, it appears that the MNS - itself collated using a web-based interface through inputs from local officials at district and regional levels - feeds directly into the MNIS. The MNS makes it possible to assess districts' progress on NMNAP implementation, enabling the TFNC to establish trends in this respect, and to provide training and capacity-building to subnational governments.

\subsubsection{Coexistence of the MNS and the Compact in the MNIS}

Key informants noted that efforts are made to ensure that there is no overlap or duplication of information, and that data from both the MNS and the Compact coexist under the MNIS.

This research attempted to obtain detailed operationalisations for both the Compact and MNS indicators. To this end, we carefully reviewed policy documents and evaluations available in the public domain, and consulted two key informants in the TFNC and PO-RALG. These efforts have resulted in a partial overview, as information was patchy, missing or simply not (made) available, which raises several questions with regards to nutrition accountability.

Findings show that the MNS has 15 'process indicators' spread across 10 nutrition-specific and nutrition-sensitive categories, which align directly with the key result areas of the NMNAP. The Compact began with 11 indicators when the contract was initially signed between PO-RALG and the 26 regional commissioners in December 2017, according to the evaluation meeting reports. However, none of these reports (that were available for review) show information for 11 indicators; the second and third evaluation reports include 10 indicators, while the fourth report and the February 2020 regional evaluation show 9 indicators. Since the fourth evaluation meeting (which took place in January 2021) is the most recent, its corresponding report will be used here to study the Compact indicators.

Figure 3.3 shows areas of overlap between the Compact and MNS indicators, and areas of difference. The nutrition-specific indicators that appear to be largely in common are shown in the centre of the Venn diagram. The figure also shows that the Compact does not share the nutrition-sensitive focus of the MNS. 


\section{Figure 3.3 The overlap in indicators between the MNS and the Compact}
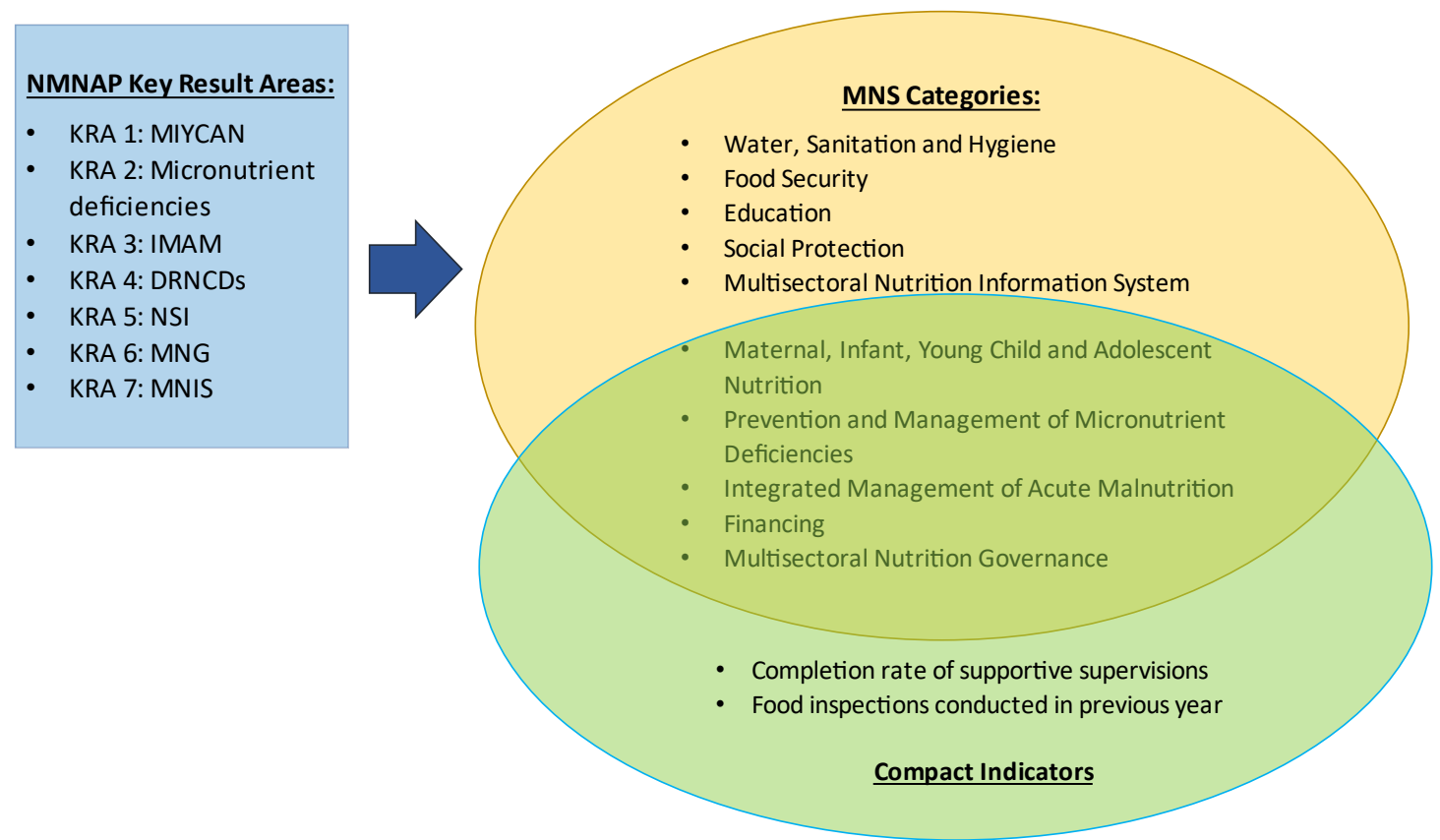

Source: Authors' own.

Note: MIYCAN (maternal, infant, young child and adolescent nutrition); DRNCD (Diet Related Non-

Communicable Diseases); NSI (nutrition-sensitive interventions); MNG (multisectoral nutrition governance).

If the MNS and the Compact do indeed co-exist under the new MNIS, we failed to understand the purpose served by having two systems with significant overlap of indicators. It is possible that the indicators they have in common have been operationalised differently. A more detailed overview of the overlap of indicators in both tools is presented in Annexe 1B. This overview suggests that where indicators appear to be in common, their operationalisation, as presented in the government reports consulted, are imprecise, and similar but not the same. We attempted to gain greater clarity on this, but could not conclusively confirm how the indicators are operationalised despite several engagements with officials in the TFNC and PO-RALG. It is evident that the government is not providing full clarity to outside observers. It is also possible that data on highly similar but not identical indicators are being collated through the MNS and the Compact, which, if confirmed to be the case, may generate significant confusion for policymakers and other stakeholders about the efforts, inputs, outputs, and possible impacts on nutrition in the country. 


\subsection{Towards what kind of nutrition accountability?}

Having set out the genesis and the substance of the MNS and the Compact, we are now in a position to reflect on the particular ways in which these express a vision on accountability for nutrition.

The detailed structure of the CRRAF, as set out in the NMNAP document, lists specific institutions and organisations as 'accountable' for achieving each output. Here, accountability is loosely used to signal which bodies have a role to play in activities addressing particular policy outputs, to highlight the intrinsic need for concerted multisectoral action towards an overarching shared goal of improving nutrition in Tanzania. For instance, the very first output - Output 1.1 on increased coverage and quality of maternal, infant, young child and adolescent nutrition (MIYCAN) services at the community level - names PO-RALG as the lead institution along with the TFNC, local government authorities, the Ministry of Health and Community Development, the United Nations, civil society organisations (CSOs) and PANITA as responsible for overseeing the work on that particular output (Government of Tanzania 2016a: 152). Yet, the ways in which an accountability relationship would function, and who can use what means to hold some other body to account for specific acts of commission or omission, remains unspecified.

The government has given significant thought and investment towards setting up and institutionalising a centralised data system (the MNIS) that can support nutrition policymaking and monitor implementation. However, through our communication with professionals engaged with these processes, it was apparent that the government's current focus is predominantly limited to the Compact. This could be for a number of reasons. First, a powerful political leader, the vice president (now president) personally initiated the Compact and is driving it forward. Second, the Compact was, from the start, a homegrown initiative, not a donor-driven one, so buy-in was strong. Third, the MNIS scorecard was the responsibility of the TFNC, a small data and capacity-building agency with no real clout at either national or subnational level. Finally, and by contrast, PO-RALG has the mandate to oversee local administrations and local officials.

Compact processes are being strengthened to streamline the upward flow of nutrition information from village to ward to district and regional levels (as has been reflected in the inclusion of the Compact in the revised CRAFF; see section 3.2). These are expected to continue well beyond the lifetime of the current NMNAP (which ends in 2021). The MNS, on the other hand, has not progressed significantly since it was established along with the publication of the NMNAP, and currently risks falling by the wayside as a nutrition accountability tool. 
Over the past decade, as part of the SUN movement, development partners have provided all kinds of nutrition-related decision-making advice to the Tanzanian government, as they financed and promoted coordination of nutrition interventions and efforts within and across government bodies. Their financial and non-financial investment in the country's nutrition actions might provide an incentive to know how the resources are being utilised and whether the progress made is on track to achieve the agreed overall targets - information that can be furnished promptly by the kind of accountability tools developed within these nutrition programmes. Yet, whereas support for the MNS provided UNICEF with detailed access to its data, it appears that the Compact's iMES platform is freestanding from shared ownership between the government and development partners.

There is significant evidence to support the conclusion that social accountability ${ }^{7}$ is low on the government's list of priorities. The NMNAP (Government of Tanzania 2016a: 82) suggests that its focus on accountability within the state apparatus is distinct from 'social accountability', which would entail civic engagement, and stimulating demand from the public towards the state to fulfil its commitments to provide quality nutrition interventions and services, and deliver on policy goals. In theory, such 'short routes' to accountability operate in conjunction with 'long routes' - i.e. through electoral processes that may hold politicians accountable. Typically, nutrition - unlike hunger - is rarely a topic of electoral significance (Berg 1973), and this is also the case in Tanzania, even though nutrition is not altogether absent from electoral manifestos of political parties (te Lintelo and Pittore 2021).

Although the NMNAP (Government of Tanzania 2016a: 83) claims to adopt a particular framework for nutrition governance as set out by Haddad, Acosta and Fanzo (2012), it does not include its recommendation to 'support civil society groups to develop social accountability mechanisms'. Where the NMNAP sets out a division of responsibilities among all state and other stakeholders, CSOs are not tasked with building social accountability. Instead, they are expected to undertake responsibilities such as advocating for prioritisation of nutrition in development plans and supporting community mobilisation around nutrition (Government of Tanzania 2016a: 91). Such responsibilities remain shy of accepting a role in holding up a critical mirror to the government. Indeed, both within the MNS and the Compact, the role of the community vis-à-vis the Tanzanian government is designed to be very limited, and at best indirect. The NMNAP further underlines this position, when it envisages social accountability as involving sporadic activities, located outside of the MNS and the Compact:

7 The World Bank's classic conceptualisation considers the complementarity between 'short routes of accountability' that entail citizens holding bureaucratic service providers to account directly for performance, whereas 'long routes' involve electoral processes holding political leaders accountable (Schedler 1999). 
Social accountability mechanisms for nutrition could include the use of a 'Nutrition Score Card' at the council level and participation of communities in monitoring implementation of the NMNAP (e.g. through the TASAF [Tanzania Social Action Fund] nutrition community sessions). Lessons from the experiences gained in the use of social accountability mechanisms in Tanzania by some stakeholders include Care's Community Score Card, CUAMM's (Doctors with Africa-Italian NGO) Beneficiary Feedback mechanism and Irish Aid's support to CSO on social accountability. Each of these provide potential applications of social accountability in the implementation of the NMNAP.

(Government of Tanzania 2016a: 82)

Strikingly, this quote does not reference the MNS, already designed and rolled out at the national level, which demonstrates that this tool is not envisaged to support social accountability.

The NMNAP's Mid-Term Review in 2019 also confirms that nothing specifically was done to advance the cause of social accountability. However, this review recognises its value and recommends that social accountability should be a focus in the next chapter of the NMNAP. Suggesting that a scorecard similar to the MNS can be considered 'for use in the community to accelerate community actions for nutrition', the Mid-Term Review recommends that social accountability should be taken up seriously in the nutrition policy that replaces the NMNAP after 2021 (Government of Tanzania 2019d: 60). Consequently, questions of social accountability are not off the radar, but deferred into the future.

Hence, it is not surprising that despite the professionalisation of institutionalised monitoring mechanisms and increasing availability of data on subnational nutrition efforts (as synthesised in the MNS and the Compact scorecards), such data are not as yet publicly available on a regular basis. Summaries of some of these scorecards for selected districts can be found within JMNR reports, which use them to outline the general direction of progress of nutrition programmes in the country. These annual JMNR reports are difficult to procure online, and fall significantly short of detailing region- or district-specific situations for each indicator that the MNS and the Compact collect data for. None of the quarterly and biannually furnished scorecards under these two tools are publicly available either. Tellingly, the team undertaking this study was unable to obtain an up-todate overview of the detailed components and definitions of key criteria included in the MNS and the Compact.

It is not just researchers who lack access to this information. Significantly, local communities whose nutrition status was considered in need of improvement face the same obstacles. Consequently, ordinary members of the public are not in a 
position to evaluate progress on nutrition goals, let alone to review programmatic inputs, outputs, and outcomes. At best, the public is involved indirectly in reviewing government performance on nutrition, through the representation of CSOs in invited platforms such as the District Steering Committees on Nutrition (DSCNs). There is some suggestion that these forums can and do discuss the MNS. However, as DSCN meetings are not minuted in any level of detail beyond the listing of agenda items, there is extremely limited evidence on any such deliberations and how they might imply a relationship of accountability for nutrition efforts and outcomes.

Moreover, as the MNS/Compact data are not officially published by the government, even while they may be discussed in DSCNs, ward development and village council meetings, they are not officially in the public domain, and subject to significant legal restrictions in its wider use and dissemination. Under the late president, John Magufuli, Tanzania witnessed a growing closure of political space for civil society groups and opposition political leaders critical of the government. The passing of the Statistics Act (2015), the Cybercrime Act (2015), the Online Content Regulations (2018), and Statistics Act (Amendments) in 2018 - the latter subsequently amended following a national and international outcry - encode in law vaguely defined offences that are punishable with minimum (potentially unlimited) jail sentences and financial penalties. CSOs such as PANITA point out that a combination of laws, including the National Security Act (Cap 47 R:E 2002) and the Statistics Act, (Cap 351 R:E 2002), the Access to Information Act 2016, and the Public Service Act 2002, in one way or another impede or undermine access to information that is held by the government. The chilling effects of the legal environment make CSOs that are officially members of these nutrition platforms fearful of sharing MNS or Compact scorecard data with other CSOs that they represent in those meetings.

Moreover, it makes government officials hesitant to share data, even in instances where official research permission has been obtained, such as for this project.

To conclude, both the MNS and the Compact data are used predominantly for internal government purposes, and continue to draw on information kept from the public domain. Within administrative levels, the tools appear to generate greater transparency and - possibly - mutual accountability between different departments' contributions to improved nutrition. However, overall, the systems are set up chiefly to serve central government needs to monitor local government (and its officials), narrowly interpreting accountability as 'vertical accountability', with data primarily moving from the subnational to the national level, all the while being collated and synthesised. Our review of the policy documents finds little evidence that analysed nutrition data are designed to come back to villages, wards and districts the data were collected from. Moreover, if the data do come back, it remains unclear what thought has been given to how frequently such feedback is organised, in what form, and whether this seeks to drive discussions 
about mutual responsibilities across administrative levels for nutrition inputs, outputs, outcomes, and impacts. Critically, the potential of the MNS and Compact scorecard data to support social accountability instruments (e.g. through publishing these on websites, or public noticeboards) is growing as data management systems are professionalising. Yet, such uses remain extremely constrained because Tanzania's political system concentrates political power at the centre, with recent autocratic political leadership unwilling to promote social accountability, and Tanzanian law paralysing data-sharing by CSOs and government officials.

What uses, then, remain to be found for the Compact and the MNS at subnational level? The next section discusses bottom-up perspectives on this, based on interviews with local-level officials. 


\section{The MNS and the Compact at subnational level: empirical evidence from interviews}

Further to our analysis so far, which had drawn particularly on an analysis of government policy documents, this section presents findings from field interviews that were conducted to understand current access to and use of the MNS and the Compact at lower government levels. A total of 204 interviews were conducted in five districts of five regions in Tanzania, during which officials from across nutrition-specific and nutrition-sensitive sectors and at district, ward, and village levels (see Annexe 2B for a list of respondents) discussed their experiences with the content and delivery of the two accountability tools. This section summarises the main learning through six key takeaways derived from our inquiry.

\subsection{Takeaway 1: Many claimed familiarity with the two tools, but only at district level}

Most of the officials interviewed claimed to be familiar with either the MNS or the Compact: 120 respondents claimed to be familiar with the two tools, whereas 83 respondents said they were not familiar with either of them. Unsurprisingly, the proportion of respondents familiar with the tools differed in all five districts. For instance, only 2 out of 37 respondents (5 per cent) in Misungwi district were unfamiliar with the tools, while 27 out of 39 respondents (almost 70 per cent) in Morogoro district were unfamiliar with them.

Among all respondents in all five districts who claimed to be unfamiliar with either the MNS or the Compact, only a small proportion belonged to the district level; the rest were all ward- or village-level officials. Figure 4.1, which illustrates this distribution, shows that awareness of and familiarity with the two accountability tools declined at lower levels of government. 


\section{Figure 4.1 Distribution by administrative level of 83 respondents who claimed to be unfamiliar with the MNS and the Compact}

\section{Those unfamiliar with the MNS and the Compact}

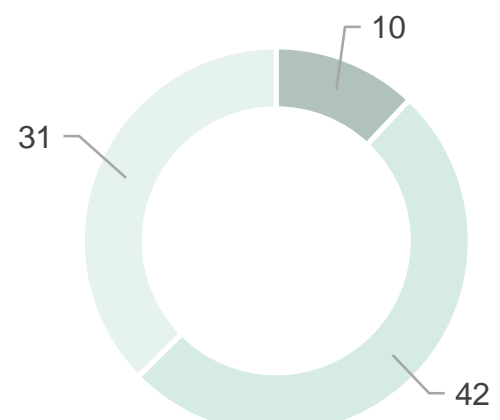

- District-level official $\quad$ Ward-level official $\quad$ Village-level official

Source: Authors' own.

This lack of awareness at sub-district levels of government was highlighted in several of the interviews. Many respondents suggested that local officials should be trained and sensitised to the operational structure of the two tools to improve their usage, as these two quotes reflect:

Ward and village leaders still do not understand [the] MNS and [the] Compact because they have not been taught.

(District education officer)

The greatest challenge is lack of awareness and knowledge, starting with the leaders down below. Hence the government should provide seminars and trainings about the MNS and nutrition issues generally. (Ward executive officer, Kishapu district)

\subsection{Takeaway 2: The tools are having several positive outcomes}

Those respondents who were familiar with the MNS and the Compact reported several positive outcomes. These include positive impacts on everyday administration of the government's nutrition agenda, which respondents saw as consequences of the implementation of the MNS and/or the Compact. Respondents claimed to have observed an increased involvement of political 
and administrative leaders. None of the respondents, however, elaborated further on the context or space in which they saw this increased participation from leaders.

Now there is much involvement of political and administrative leaders, which was quite different before the MNS and the Compact systems were introduced.

(Deputy district executive director)

Similarly, a number of respondents mentioned increased 'cooperation and assistance from the top levels of administration'. While their answers did not go into detail on the kind of cooperation and assistance extended by the top administrative leaders, these were offered by officials at all three levels (district, ward, and village), suggesting that the accountability tools are already generating downward cascading effects within the bureaucracy.

Some officials reported a third positive outcome, in that the tools have started to address the need for better vertical and horizontal coordination between councils and departments. There was mention of cooperation between districts and wards, districts and villages, and wards and villages, while some respondents pointed to increased horizontal cooperation between different departments:

The cooperation and assistance between the council and ward has improved as the data collected starts from the grass roots (villages) to the top level of administration (the district council). (Ward councillor, Misungwi district)

The MNS... has enabled nutrition issues to be linked with other sectors, e.g. agriculture and livestock departments.

(Ward nursing officer, Kishapu district)

Finally, several interviewees pointed to greater participation of community members in nutrition activities than before (see quote), and an increased awareness of nutrition issues. Although this is unlikely to be a direct outcome of the MNS or the Compact, a perceived increase in community engagement around nutrition could potentially be leveraged to advance social accountability for nutrition.

Currently, there is greater participation of community in nutrition projects than before. This helps our nutrition goal to reduce malnutrition.

(Ward councillor, Mbeya district) 


\subsection{Takeaway 3: Local officials struggle to distinguish between the tools}

The third key takeaway from the interviews diminishes our faith in the perceived positive outcomes reported under takeaway 2 , as a significant proportion of respondents who claimed to be familiar with either the MNS or the Compact could not distinguish them from one another, nor from other tools and programmes implemented by government. This was evident in answers to several questions, where officials alluded to factors that had little to do with either the MNS or the Compact. Having observed answers from across the five districts, we can group those respondents who claimed familiarity with the MNS and/or the Compact into three groups: (1) officials who mentioned specific aspects of the two tools, thereby objectively showing their use and knowledge of them; (2) officials who had a vague idea about the tools, and hence referred to general nutrition goals instead of elements specific to the MNS or the Compact; and (3) officials who had clearly confused the two tools for other instruments or government policies.

This can be best illustrated by listing the answers received for any one particular question. Question A3, for instance, asked respondents if they had ever made use of the information or data from the MNS or Compact systems, and if yes, how. Below are the responses received from each category of respondents discussed in the previous paragraph. In short, these are the ways in which the officials claimed to have used the MNS or Compact data:

\section{a. Answers from those who accurately pointed to features and functions of the MNS and the Compact:}

i. Collects information on the indicators within the MNS and the Compact.

ii. To report on the percentage of quarterly and annual nutrition meetings convened.

iii. To oversee the performance of local public employees such as community health workers.

iv. To monitor nutrition activities such as vitamin A supplementation.

v. To bring up nutrition issues in official meetings using statistics from the scorecards.

vi. To identify the biggest nutrition challenges.

vii. To share information on nutrition with other departments. 


\section{b. Answers from those who vaguely alluded to aspects within the MNS and the Compact:}

i. To plan and strategise nutrition activities.

ii. To draw up or approve the budget for the district.

iii. To draw up the budget for nutrition activities.

iv. To identify places with water shortages.

v. To borrow funds for nutrition activities.

vi. To monitor the working capacity of the health department.

vii. To monitor effectiveness of nutrition activities and programmes.

viii. To distribute nutrition supplements among the population.

ix. To plan Nutrition Day in the community.

\section{c. Answers from those who listed uses of the MNS and the Compact that have nothing to do with either of the two tools:}

i. To compare implementation of nutrition programmes between wards and villages.

ii. To monitor nutrition status and outcomes in the wards and villages.

iii. To identify women who require iron and folic acid supplementation.

iv. To identify households with malnourished children.

v. For planning horticultural activities such as farm trainings, plant treatment, buying materials for pocket gardening, etc.

vi. For planning agricultural activities by promoting and supporting increased production, availability, accessibility, and consumption of diverse highnutrient food crops.

vii. For planning livestock and fisheries-related activities.

viii. For provision of loans to farmers and livestock keepers.

ix. To educate the community on use of water to enhance nutrition.

x. To provide individual nutrition counselling around dispensaries.

xi. To monitor the extent of vaccination among children.

xii. To identify areas not using iodised salt.

xiii. To identify HIV-positive children.

xiv. To plan awareness and other nutrition-related activities in schools. 
xv. To present poultry data such as amount of meat, milk, and eggs that have been used in a quarter.

xvi. To provide loans to women at 4 per cent interest.

Attributes assigned incorrectly to the MNS and the Compact featured in answers for all ten questions in the questionnaire. Therefore, awareness of the detailed workings of the MNS and the Compact is low even among officials who claimed to be familiar with the two tools.

\subsection{Takeaway 4: Ties with community mobilisation and awareness}

Respondents frequently associated the MNS and the Compact with outcomes seemingly tied to social accountability. Officials working in various government levels in all five districts pointed to aspects such as social awareness and community engagement when answering the questions. For instance, some respondents claimed to have used the information from the MNS and the Compact to conduct awareness programmes and nutrition education in the community.

He uses the MNS in implementing community activities such as planning of events that are focused on disseminating nutrition and health education to the society.

(Village executive officer, Kishapu district)

More than 50 respondents claimed that other officials - such as elected councillors and members of nutrition steering committees in the districts, wards, and villages - used the MNS and the Compact to engage and mobilise the community around nutrition:

The elected councillors and district nutrition committees use MNS and Compact data for motivating community members to participate in different activities conducted by the district committee and at ward level. For example, by motivating ward members and community members to participate in nutrition campaigns (such as Nutrition Day), nutrition training and meetings, which are conducted once every three months.

(District medical officer)

When asked about the main achievements of the MNS and the Compact systems, respondents most commonly mentioned that the community was now more aware of nutrition issues: 
The MNS has helped the community to understand the importance

of having good nutrition and proper feeding practices.

(Ward nursing officer, Kishapu district)

While respondents associate community engagement around nutrition with the tools at hand, they did not go into detail about how the two are objectively connected. In contrast, a few responses, especially from Morogoro district, highlighted that improved community awareness on nutrition is a general trend in recent years, and not necessarily a result of the MNS or the Compact. We may, however, consider that improved community awareness or mobilisation around nutrition issues could be the outcome of indirect, idiosyncratic efforts by enterprising officials using the MNS and/or the Compact. We say 'indirect' because neither the MNS nor the Compact are specifically aimed at such mobilisation, and 'idiosyncratic' as it appears from all our evidence presented prior to this section that these tools are not designed for such a purpose. Even if this is happening widely, its modus of spreading nutrition awareness among citizens using scorecards through top-down processes does not equate to fostering social accountability. Moreover, interviews provided limited evidence regarding involvement of communities, CSOs or faith-based organisations in discussion of local nutrition issues with government officials, including through the formal channels of the nutrition steering committees. Some respondents spontaneously commented on their participation, with one noting that their views were not heard in nutrition steering committee meetings:

He did not expect that their views with regard to various nutrition issues in the community would not be heard. Thus this is one of the negative experiences he has had since he became a member of the district nutrition steering committee.

(Religious institutions' representative in a district steering committee on nutrition)

District nutrition steering committee meetings act as invited spaces for community representatives to provide their views, and while we can record attendance, the minutes provide no insights into the nature of discussions and any decisions taken in these platforms.

\subsection{Takeaway 5: Data collected do not return to wards and villages}

There was little in the interview answers to suggest that data collected through the MNS and the Compact are fed back to wards and villages for local councils to discuss or act upon. One possible reason for this could be the lack of vertical communication (between government levels) on nutrition issues - a factor highlighted by officials in all districts: 
In order to ensure accountability for nutrition there should be cooperation and unity between low and high government levels. Information is truly collected but there should be feedback to where data were collected [from]. The feedback will help understand where the problem is and how they can solve the problem from top to the bottom level of leadership.

(District TASAF officer)

The only thing that needs to be improved is to have reliable communication from the district council to the village council. Sometimes, there is information cut off, which causes insufficient implementation of nutrition activities at the lower levels (villages). (District information officer)

There is no close collaboration between district council and ward council, which leads to miscommunication and unfinished nutrition activities, particularly in the lower level. Without clear communication, many nutrition activities will be left unimplemented. (District welfare officer)

Comments such as those, which highlight the lack of a feedback loop, suggest that information (in the case of the MNS and the Compact) flows in one direction only: upward. If the information collected from these ward and village councils to furnish district and regional nutrition scorecards is not relayed back to the same wards and villages, it inhibits the awareness of local nutrition issues, both among local leaders and, indirectly, to the community at large. This lack of awareness among local leadership and citizens represents a challenge recognised by more than 60 officials.

One of the things that he did not expect from implementation of the MNS was the fact that the ward and village executive officers are still not presenting the nutrition situation information of their wards and villages respectively in the noticeboards of their offices. He also said that the ward and village local government leaders are not informing their citizens of information they get from meetings that have nutrition agendas'.

(District NGO representative)

He said the key challenge is lack of experts that reach out to us and train us on nutrition matters because nutrition challenges are still troubling us and since we don't even know what's nutrition, we do not even understand where we should start to address these challenges.

(Village executive officer, Kigoma village) 


\subsection{Takeaway 6: The missing link: accountability}

The sixth and final takeaway from the analysis of the field interviews is that the officials interviewed did not attach either a social accountability or a vertical accountability logic to the MNS and Compact systems. Although a few answers did include the word 'accountability', they did not elaborate - for instance, on how the scorecards within the two tools helped make officials working on nutrition actions more accountable for the performance of the wards and villages under their supervision. This suggests that officials at lower government levels do not regard the MNS and the Compact as accountability tools, not even in the manner that the policymakers drafting the country's nutrition policies do. 


\section{Discussion and conclusion}

Over the past decade, and starting with the NNS in 2011, accountability has been given increasing attention in the Tanzanian government's nutrition policy. Annual nutrition reviews at the national level (JMNRs) were constituted in 2014, to recommend development of a framework (CRRAF) to track the progress of the NNS and its successor, the NMNAP. Along the way, 'accountability tools' such as the MNS and the Compact were devised to inform the CRRAF and guide efforts towards NMNAP objectives.

The national MNIS has been established to bring together and streamline the flow of nutrition-related information from multiple sectoral information systems, diverse data sources (such as national nutrition surveys) and newly instituted accountability tools such as the MNS and the Compact. Automation is enabling the use of highly organised nutrition data, faster and in significantly greater detail than was previously possible. By enhancing transparency of efforts by diverse government actors, they facilitate multisectoral coordination on nutrition issues at the national and subnational levels.

Crucially, data management systems and accountability tools are devised to enable administrative and political oversight and control by central authorities to monitor and hold local government bodies accountable for nutrition activities, outputs, outcomes, and impacts. Accountability is thus mainly interpreted as 'vertical accountability', largely conceived and developed in the service of a heavily centralised state, while the general public is kept at arm's length. Our evidence shows that the MNS and the Compact, for instance, are designed to be strictly for internal government purposes only; none of the information collected quarterly and biannually from districts and regions by the MNS and Compact scorecards is publicly available. Moreover, data travels primarily from lower to higher levels of administrations, and feedback loops to inform subnational administrations are significantly under-developed.

Such a closed conception of accountability does not help build a relationship between citizens and government 'based on transparency, accountability and participation' (Government of Tanzania 2016a: 82). The NMNAP stresses the need to build 'social accountability' where the public can hold state actors accountable for performance on nutrition targets, but stops short of explicitly laying out a roadmap to build that. Social accountability is at best a peripheral feature of the MNS and Compact instruments. The NMNAP's Mid-Term Review in 2019 documents the fact that nothing was done to include the role of the community in strengthening nutrition accountability, leaving it as a recommendation for the next nutrition strategy to pick up (Government of 
Tanzania 2019d: 60). As such, social accountability is clearly not a priority, as action on it has been deferred.

This research effort was significantly hampered by the lack of data and limited detail published on the operationalisation of the MNS and the Compact. Consequently, questions remain about the distinctness of each tool: while the Compact does not share the nutrition-sensitive focus of the MNS, nutritionspecific indicators appear to be held in common. Yet, operationalisations of indicators presented in published government documents lack specificity and precision. If the MNS and the Compact co-exist under the newly developed MNIS, we fail to understand the purpose served by having two synonymous systems with such a significant overlap of indicators. It is possible that the seemingly common indicators within the two tools have been operationalised differently, but we could not confirm this despite several engagements with officials in the TFNC and PO-RALG. There is hence a possibility that data on highly similar but not identical indicators are being collated through the MNS and the Compact separately - a practice that may generate confusion for policymakers and other stakeholders.

Field interviews with 204 local officials across the five districts in five regions complemented our policy document analysis, offering insights into current access to and use of the MNS and the Compact at district, ward, and village levels. About two in three respondents claimed to be familiar with the two tools; those who were not familiar with them were largely concentrated at ward and village levels - i.e. those furthest removed from central administrative oversight. Several respondents cited positive outcomes of implementation of the MNS and the Compact, including increased involvement of political and administrative leaders, better vertical and horizontal coordination on nutrition between departments and administrations, and greater community participation in nutrition activities. However, these claims need to be seen against a backdrop of substantial confusion among respondents about the two tools, and their conflation with other nutrition-related tools and government programmes/policies.

Respondents noted that data collected through the MNS and the Compact did not return to the wards and villages for local councils to discuss or act upon. Occasional idiosyncratic initiatives by local officials to use these tools to generate community awareness on nutrition matters cannot be ruled out. Importantly though, interviews offered scant evidence to suggest that the MNS and Compact scorecards are used to promote social accountability around nutrition.

Indeed, few respondents ascribed an 'accountability logic' to the MNS and Compact systems, even though they have been labelled as 'accountability tools' in policy documents. This suggests a discrepancy in how national policymakers and development partners supporting government policymaking envision the 
MNS and the Compact and how they talk about (social) accountability and community participation, and their conceptual and practical remoteness to local officials having grounded knowledge of the day-to-day functioning of government bureaucracy.

To conclude, the Tanzanian government has, over the past decade, put in place substantial efforts to increase spending, institutionalise evidence-gathering mechanisms on the outputs, outcomes, and impacts of nutrition programming, and innovate by introducing new incentives for politico-administrative leadership at subnational level. These efforts are largely in the service of a centralised state, towards advancing vertical accountability. Significant barriers continue to inhibit greater accountability of the Tanzanian state towards its citizens for nutrition, and it is clear that social accountability is deprioritised, to hold back advances towards nutrition security for many of its citizens. 


\section{Annexe 1: From the review of policy documents}

The following annexes relate to the text in section 3: Vision on nutrition accountability expressed in nutrition documents.

\section{Annexe 1A: On the Compact's operational structure}

Here are some examples from the Compact evaluation meeting reports, which demonstrate a consistent effort to place the onus of implementing the Nutrition Compact on the lower levels of government, thereby reflecting the Compact's place and purpose in the broader picture of nutrition governance in Tanzania.

\section{Table A1 Excerpts from policy documents regarding implementation of the Compact}

\begin{tabular}{|c|c|c|}
\hline Instance & Appeared as & Appeared in \\
\hline $\begin{array}{l}\text { Regions should analyse the performance } \\
\text { of Compact indicators per council, to be } \\
\text { able to identify councils that are dragging } \\
\text { down the performance of the respective } \\
\text { regions. }\end{array}$ & $\begin{array}{l}\text { A statement by } \\
\text { Seleman Jafo, } \\
\text { Minister of } \\
\text { State for PO- } \\
\text { RALG }\end{array}$ & $\begin{array}{l}\text { Second } \\
\text { Evaluation } \\
\text { Meeting Report } \\
\text { of the Compact, } \\
19 \text { March } 2019 \\
\text { (Government of } \\
\text { Tanzania 2019c) }\end{array}$ \\
\hline $\begin{array}{l}\text { Due to shortage of nutrition officers in } \\
\text { councils, regions should ensure that other } \\
\text { experts such as Community } \\
\text { Development, Social Welfare and } \\
\text { Agriculture extension officers are } \\
\text { capacitated to provide nutrition education } \\
\text { to the community, as efforts to recruit } \\
\text { nutrition experts are underway. }\end{array}$ & $\begin{array}{l}\text { A statement by } \\
\text { Seleman Jafo, } \\
\text { Minister- of } \\
\text { State for PO- } \\
\text { RALG }\end{array}$ & $\begin{array}{l}\text { Second } \\
\text { Evaluation } \\
\text { Meeting Report } \\
\text { of the Compact, } \\
19 \text { March } 2019 \\
\text { (ibid.) }\end{array}$ \\
\hline
\end{tabular}

(Cont'd.) 


\section{Table A1 (cont'd.)}

\begin{tabular}{|c|c|c|}
\hline Instance & Appeared as & Appeared in \\
\hline $\begin{array}{l}\text { Regions should continue to conduct } \\
\text { evaluation biannually in order to track } \\
\text { the performance of compact indicators } \\
\text { per councils, to identify councils that } \\
\text { have poor performance through the } \\
\text { Integrated Monitoring and Evaluation } \\
\text { System (iMES) and take necessary } \\
\text { actions. }\end{array}$ & $\begin{array}{l}\text { A recommendation } \\
\text { from meeting } \\
\text { discussions }\end{array}$ & $\begin{array}{l}\text { Third } \\
\text { Evaluation } \\
\text { Meeting Report } \\
\text { of the Compact, } \\
24 \text { August } 2019 \\
\text { (Government of } \\
\text { Tanzania } \\
\text { 2019b) }\end{array}$ \\
\hline $\begin{array}{l}\text { He (Minister of State for PO-RALG) } \\
\text { also congratulated all regional } \\
\text { commissioners who have trickled down } \\
\text { the Compact agreement to district } \\
\text { commissioners, district executive } \\
\text { directors then to ward and village/ } \\
\text { street executive officers in order to } \\
\text { administer the implementation of } \\
\text { nutrition interventions to their levels of } \\
\text { jurisdiction. }\end{array}$ & $\begin{array}{l}\text { Part of the } \\
\text { summary of } \\
\text { meeting } \\
\text { discussion }\end{array}$ & $\begin{array}{l}\text { Third } \\
\text { Evaluation } \\
\text { Meeting Report } \\
\text { of the Compact, } \\
24 \text { August } 2019 \\
\text { (ibid.) }\end{array}$ \\
\hline $\begin{array}{l}\text { To raise a sense of ownership on } \\
\text { Nutrition Performance Compact } \\
\text { Agreement evaluation at regional level. }\end{array}$ & $\begin{array}{l}\text { One of the } \\
\text { objectives of the } \\
\text { meeting }\end{array}$ & $\begin{array}{l}\text { Regional-level } \\
\text { Compact } \\
\text { Evaluation } \\
\text { Report, } \\
\text { February } 2020\end{array}$ \\
\hline $\begin{array}{l}\text { All regions to ensure their councils } \\
\text { commit to execute domestic fund } \\
\text { allocated for nutrition interventions. }\end{array}$ & $\begin{array}{l}\text { A recommendation } \\
\text { of the evaluation } \\
\text { meeting }\end{array}$ & $\begin{array}{l}\text { Regional-level } \\
\text { Compact } \\
\text { Evaluation } \\
\text { Report, } \\
\text { February } 2020\end{array}$ \\
\hline $\begin{array}{l}\text { Nutrition reports should be discussed } \\
\text { at council level before submission to } \\
\text { PO-RALG. }\end{array}$ & $\begin{array}{l}\text { A recommendation } \\
\text { of the evaluation } \\
\text { meeting }\end{array}$ & $\begin{array}{l}\text { Regional-level } \\
\text { Compact } \\
\text { Evaluation } \\
\text { Report, } \\
\text { February } 2020\end{array}$ \\
\hline
\end{tabular}

\section{Annexe 1B: On the overlap of indicators between the MNS and the Compact}

A 2018 draft of the MNS shared by the TFNC shows that the scorecard has 15 'process indicators' spread across ten nutrition-specific and nutrition-sensitive categories, which align directly with the key result areas (KRA) of the NMNAP. However, as is apparent from Table 5.1, the MNS does not have a category that 
corresponds to KRA 4 of the NMNAP (which is related to Diet Related NonCommunicable Diseases or DRNCDs).

Information for the 15 MNS indicators is collected quarterly at the district level, and collated biannually and annually, according to the TFNC. When compared to the indicators included in the Compact, four MNS categories are seen to overlap.

\section{Table A2 Similarities in indicator focus in the MNS and the Compact}

\begin{tabular}{|c|c|c|}
\hline \multicolumn{2}{|c|}{ Multisectoral scorecard (MNS) } & \multirow[t]{2}{*}{ Compact indicator } \\
\hline Category & Indicator & \\
\hline \multirow[t]{2}{*}{$\begin{array}{l}\text { Maternal, infant, } \\
\text { young child and } \\
\text { adolescent } \\
\text { nutrition }\end{array}$} & \multirow{2}{*}{$\begin{array}{l}\text { Indicator 1: Proportion of } \\
\text { mothers of children aged 0-23 } \\
\text { months who have received } \\
\text { counselling on infant and young } \\
\text { child feeding (breastfeeding } \\
\text { and complementary feeding) } \\
\text { from a community health } \\
\text { worker in the reporting period }\end{array}$} & $\begin{array}{l}\text { Indicator 4: Maternal } \\
\text { infant young children and } \\
\text { adolescent nutrition } \\
\text { counseling }[\mathrm{sic}] \text { provided } \\
\text { at the health facilities }\end{array}$ \\
\hline & & $\begin{array}{l}\text { Indicator } 5 \text { : Nutrition } \\
\text { education and counseling } \\
\text { [sic] to caregivers at } \\
\text { community level }\end{array}$ \\
\hline \multirow[t]{2}{*}{$\begin{array}{l}\text { Prevention and } \\
\text { management of } \\
\text { micronutrient } \\
\text { deficiencies }\end{array}$} & $\begin{array}{l}\text { Indicator } 2 \text { : Proportion of } \\
\text { children aged } 6-59 \text { months who } \\
\text { have received vitamin A } \\
\text { supplements in the previous } 6 \\
\text { months }\end{array}$ & $\begin{array}{l}\text { Indicator 2: Vitamin A } \\
\text { supplementation to } \\
\text { children aged 6-59 } \\
\text { months }\end{array}$ \\
\hline & $\begin{array}{l}\text { Indicator 3: Proportion of } \\
\text { pregnant women who received } \\
\text { any iron folic acid (IFA) in the } \\
\text { reporting period }\end{array}$ & $\begin{array}{l}\text { Indicator 3: Iron and folic } \\
\text { acid (FeFO) } \\
\text { supplementation to } \\
\text { pregnant women }\end{array}$ \\
\hline $\begin{array}{l}\text { Integrated } \\
\text { Management of } \\
\text { Acute } \\
\text { Malnutrition } \\
\text { (IMAM) }\end{array}$ & $\begin{array}{l}\text { Indicator } 4 \text { : Proportion of } \\
\text { expected cases of severe acute } \\
\text { malnutrition (SAM) among } \\
\text { children aged } 0-59 \text { months who } \\
\text { were admitted for treatment in } \\
\text { the IMAM service in the } \\
\text { reporting period }\end{array}$ & $\begin{array}{l}\text { Indicator } 6 \text { : Percent of } \\
\text { malnourished children } \\
\text { identified and received } \\
\text { treatment }\end{array}$ \\
\hline
\end{tabular}

(Cont'd.) 
Table A2 (cont'd.)

\begin{tabular}{|c|c|c|}
\hline \multicolumn{2}{|c|}{ Multisectoral scorecard (MNS) } & \multirow[t]{2}{*}{ Compact indicator } \\
\hline Category & Indicator & \\
\hline \multirow{3}{*}{$\begin{array}{l}\text { Multisectoral } \\
\text { Nutrition } \\
\text { Governance }\end{array}$} & $\begin{array}{l}\text { Indicator 12: Implementation } \\
\text { rate of annual nutrition plan }\end{array}$ & \\
\hline & $\begin{array}{l}\text { Indicator 13: Proportion of } \\
\text { council budget spent on } \\
\text { nutrition activities }\end{array}$ & $\begin{array}{l}\text { Indicator 1: Domestic } \\
\text { fund spent by council }\end{array}$ \\
\hline & $\begin{array}{l}\text { Indicator 14: Status of council } \\
\text { nutrition steering committee } \\
\text { meetings held }\end{array}$ & $\begin{array}{l}\text { Indicator } 7: \text { Completion } \\
\text { rate of Multisectoral } \\
\text { Nutrition Steering } \\
\text { Committee meetings }\end{array}$ \\
\hline
\end{tabular}

The table shows that the Compact concerns itself more with nutrition-specific indicators and financial resource management, while the MNS monitors nutritionsensitive interventions in addition to both of those areas monitored by the Compact. Both tools collect information from lower levels of administration: while the MNS includes nutrition data from districts, which are subsequently aggregated at the regional level, the Compact collects data from the community and health service providers and aggregates them at council level.

The following is a list of MNS and Compact indicators for comparison. Scorecard indicators in bold (below) are understood to be common among the MNS and the Compact. The degree and extent of this commonality could not be confirmed due to lack of access to official resources on how these indicators are operationalised. This comparison is instead based solely on the phrasing of the indicators in official and internal documents of the TFNC and PO-RALG.

\section{MNS indicators:}

- Category 1: Maternal, infant, young child and adolescent nutrition

1. Proportion of mothers of children aged 0-23 month who have received counselling on infant and young child feeding (breastfeeding and complementary feeding) from a community health workers in the reporting period

- Category 2: Prevention and management of micronutrient deficiencies

2. Proportion of children aged 6-59 months who have received vitamin A supplements in the previous six months 
3. Proportion of pregnant women who received any iron folic acid (IFA) in the reporting period

- Category 3: Integrated management of acute malnutrition

4. Proportion of expected cases of SAM among children aged 0-59 months who were admitted for treatment in the IMAM service in the reporting period

- Category 4: NS - Water, sanitation and hygiene

5. Proportion of households with improved latrines in the reporting period

6. Proportion of households with access to clean and safe water

7. Proportion of households with functional handwashing facilities in the reporting period

- Category 5: NS - Food security

8. Proportion of households with food insecurity

- Category 6: NS - Education

9. Proportion of females in secondary school enrollment

- Category 7: NS - Financing

10.Proportion of council budgets allocated funds for nutrition

- Category 8: NS - Social protection

11. Proportion of vulnerable households benefiting from social protection programmes (conditional cash transfers, cash for work, and nutrition education during community sessions) who received nutrition education in the reporting period

- Category 9: Multisectoral nutrition governance

12. Implementation rate of annual nutrition plan

\section{Proportion of council budget spent on nutrition activities}

\section{Status of council nutrition steering committee meetings held}

- Category 10: Multisectoral nutrition information system

15.Data completeness 
Nutrition Accountability through Sub-National Scorecards in Tanzania - Policy Innovations and Field Realities

\section{Compact indicators:}

Indicator 1: Domestic fund spent by council

Indicator 2: Vitamin A supplementation to children aged 6-59 months Indicator 3: Iron and folic acid (FeFo) supplementation to pregnant women Indicator 4: Maternal infant young children and adolescent nutrition counseling provided at the health facilities

Indicator 5: Nutrition education and counseling to caregivers at community level

Indicator 6: Percent of malnourished children identified and received treatment

Indicator 7: Completion rate of Multisectoral Nutrition Steering Committee meetings

Indicator 8: Completion rate of supportive supervision conducted

Indicator 9: Food inspection conducted in year 2019/20 


\section{Annexe 2: From the field interviews}

The following annexes relate to the text in section 4: The MNS and the Compact at subnational level: empirical evidence from interviews.

\section{Annexe 2A: Questionnaire for the interviews}

\section{Figure A1 Questionnaire used in the field interviews}

\begin{tabular}{|l|l|l|l|}
\hline Location & \multicolumn{2}{|l|}{} & \multicolumn{2}{|l|}{ Time } & \\
\hline Interviewer & & Role in council & \\
\hline Interviewee & & & \\
\hline Date of interview & & Type of interview & \\
& & & \\
\hline
\end{tabular}

Nutrition Committee member profile:

a. Access to and use of the MNS and the Compact

1. As a member of the District Development Committee, find out what are his/her main roles in the council.

2. Find out if he/she is familiar with the MNS and Compact information systems (what they are, and what kind of information/data they consist of.)

3. Find out if he/she has ever made use of the information/data from the MNS and Compact systems. 
4. Probe to find out the main uses of the MNS and the Nutrition Compact indicators/data (e.g. planning, monitoring, community engagement, etc.), and by whom.

5. In what ways are the elected councillors and the District Nutrition Steering Committees making use of the MNS and Compact data?

6. Probe to find out if there are some aspects of the MNS and the Compact that are not clear to them, or still need to be strengthened to foster social accountability.

7. With respect to protecting some of the most vulnerable population groups such as women of reproductive age and children, find out how he/she feels about how the MNS/Compact is addressing these needs.

\section{What is working well and not so well in the MNS and the Compact?}

1. Find out what he/she considers to be the main achievements of the MNS and the Compact so far.

2. What does he/she feel should be kept the same or slightly improved in the content or delivery of the MNS and the Compact? (Probe: What are the key challenges, what does not work well and why?)

3. Find out if there is anything that is happening (positive and negative) from implementing the MNS and the Compact that he/she did not expect. 


\section{Annexe 2B: List of respondents}

Table A3 illustrates the extent of the field interview exercise, results of which have been analysed in section 4 .

\section{Table A3 Field interview respondents in the five Tanzanian districts}

\begin{tabular}{|c|c|c|c|c|}
\hline District & District level & Ward level & Village level & Total \\
\hline Kigoma & $\begin{array}{l}\text { Nutrition officer, Nutrition } \\
\text { Coordinator, Community } \\
\text { Development Officer, Deputy } \\
\text { District Executive Director, } \\
\text { Education Officer, } \\
\text { Immunisation Officer, IT } \\
\text { Officer, Medical Officer, } \\
\text { Health Officer, Human } \\
\text { Resource Officer, Livestock } \\
\text { and Fisheries Officer, } \\
\text { Planning Officer, } \\
\text { Reproductive and Child } \\
\text { Health Officer, TASAF Officer }\end{array}$ & $\begin{array}{l}2 \text { Ward } \\
\text { Councillors, } 1 \\
\text { Council } \\
\text { Chairperson, } 3 \\
\text { Ward Executive } \\
\text { Officers, } 2 \\
\text { Agricultural } \\
\text { Officers, } 1 \\
\text { Council Member, } \\
1 \text { Education } \\
\text { Officer, } 1 \\
\text { Community } \\
\text { Development } \\
\text { Officer }\end{array}$ & $\begin{array}{l}8 \text { Village } \\
\text { Chairpersons, } 8 \\
\text { Village } \\
\text { Executive } \\
\text { Officers }\end{array}$ & 44 \\
\hline Kishapu & $\begin{array}{l}\text { Nutrition Officer, Health } \\
\text { Information System Officer, } \\
\text { Agriculture Officer, Christian } \\
\text { Representative, Muslim } \\
\text { Representative, Community } \\
\text { Development Officer, Health } \\
\text { Officer, District Executive } \\
\text { Director, Development } \\
\text { Officer, District Secretary, } \\
\text { HIV-AIDS Coordinator, IT } \\
\text { Officer, Livestock and } \\
\text { Fisheries Officer, Medical } \\
\text { Officer, Primary School } \\
\text { Officer, Reproductive and } \\
\text { Child Health Officer, Rural } \\
\text { Water Supply Officer, Social } \\
\text { Welfare Officer, Treasurer }\end{array}$ & $\begin{array}{l}4 \text { Headmasters, } \\
1 \text { School } \\
\text { Teacher, } 2 \\
\text { Agriculture } \\
\text { Officers, } 3 \text { Ward } \\
\text { Executive } \\
\text { Officers, } 2 \\
\text { Livestock } \\
\text { Officers, } 1 \\
\text { Nursing Officer, } 1 \\
\text { Community } \\
\text { Development } \\
\text { Officer }\end{array}$ & $\begin{array}{l}7 \text { Village } \\
\text { Chairpersons, } 6 \\
\text { Village } \\
\text { Executive } \\
\text { Officers, } 1 \\
\text { Village } \\
\text { Representative }\end{array}$ & 49 \\
\hline
\end{tabular}




\begin{tabular}{|c|c|c|c|c|}
\hline Mbeya & $\begin{array}{l}\text { Nutrition Officer, Education } \\
\text { Officer (secondary schools), } \\
\text { Information Officer, } \\
\text { Community Development } \\
\text { Officer, Finance Officer, } \\
\text { Horticulture Officer, Human } \\
\text { Resource Officer, Medical } \\
\text { Officer, Planning Officer, } \\
\text { Education Officer (primary } \\
\text { schools), Welfare Officer, } \\
\text { Livestock Officer }\end{array}$ & $\begin{array}{l}4 \text { Ward Executive } \\
\text { Officers, } 2 \text { Ward } \\
\text { Agriculture } \\
\text { Officers, } 2 \\
\text { Community } \\
\text { Health Workers, } \\
2 \text { Ward Medical } \\
\text { Officers, } 2 \\
\text { Community } \\
\text { Development } \\
\text { Officers, } 2 \text { Ward } \\
\text { Councillors, } 1 \\
\text { Community } \\
\text { Welfare Officer, } 1 \\
\text { Headmaster, } 1 \\
\text { Cooperative } \\
\text { Leader }\end{array}$ & $\begin{array}{l}3 \text { Village } \\
\text { Chairpersons, } 5 \\
\text { Village } \\
\text { Executive } \\
\text { Officers, } 2 \\
\text { Hamlet Leaders }\end{array}$ & 40 \\
\hline Misungwi & $\begin{array}{l}\text { Nutrition Officer, Agriculture } \\
\text { Officer, Community } \\
\text { Development Officer, Deputy } \\
\text { Executive Director, Education } \\
\text { Officer (primary schools), } \\
\text { Education Officer (secondary } \\
\text { schools), Health Officer, } \\
\text { Human Resource Officer, } \\
\text { Livestock and Fisheries } \\
\text { Officer, Livestock Officer, } \\
\text { Medical Officer, NGOs } \\
\text { representative, Planning } \\
\text { Officer, TASAF Officer, } \\
\text { Treasurer, District Water } \\
\text { Engineer }\end{array}$ & $\begin{array}{l}2 \text { Ward } \\
\text { Councillors, } 2 \\
\text { Ward Executive } \\
\text { Officers, } 3 \text { Ward } \\
\text { Agriculture } \\
\text { Officers, } 2 \text { Ward } \\
\text { Education } \\
\text { Officers, } 3 \text { Ward } \\
\text { Livestock } \\
\text { Officers, } 1 \\
\text { Community } \\
\text { Development } \\
\text { Officer, } 2 \text { Ward } \\
\text { Health Officers }\end{array}$ & $\begin{array}{l}1 \text { Village } \\
\text { Chairperson, } 5 \\
\text { Village } \\
\text { Executive } \\
\text { Officers }\end{array}$ & 37 \\
\hline
\end{tabular}


Nutrition Accountability through Sub-National Scorecards in Tanzania - Policy Innovations and Field Realities

\begin{tabular}{|l|l|l|l|l|}
\hline Morogoro & Nutrition Officer, Treasurer, 2 & 3 Ward & 2 Village & 39 \\
& Religious Institutions & Agriculture & Chairperson, 3 & \\
Representatives, Agriculture & Officers, 2 Ward & Village & \\
Officer, Community & Community & Executive \\
Development Officer, Council & Development & Officers & \\
Committee Clerk, Education & Officers, 3 Ward & & \\
Officer (secondary schools), & Education & & \\
Health Education & Officers, 3 Ward & & \\
Coordinator, Human & Executive & & \\
Resource Officer, Information & Officers, 3 Ward & & \\
& Technology Officer, Livestock & Livestock & & \\
& Officer, Medical Officer, & Officers, 1 Ward & & \\
NGOs Representative, & Health Officer, 1 & & \\
Planning Officer, Private & Ward Councillor, & & \\
Sector Representative & 1 Ward Forestry & & \\
& Officer, 1 Ward & \\
& Water Officer & & \\
& &
\end{tabular}


Nutrition Accountability through Sub-National Scorecards in Tanzania - Policy Innovations and Field Realities

\section{References}

Berg, A. (1973) The Nutrition Factor: Its Role in National Development, Washington DC: Brookings Institution

Blake, C. et al. (2016) 'Scorecards and Social Accountability for Improved Maternal and Newborn Health Services: A Pilot in the Ashanti and Volta Regions of Ghana', International Journal of Gynecology \& Obstetrics 135.3: 372-79 (accessed 12 November 2021)

Government of Tanzania (2019a) Tanzania National Nutrition Survey 2018, Dar es Salaam: Government of Tanzania, University of Dodoma, development partners and UNICEF

Government of Tanzania (2019b) Third Evaluation Meeting Report on Nutrition Compact Implementation, Dodoma: President's Office - Regional Administration and Local Government

Government of Tanzania (2019c) Report on the Second Evaluation Meeting of the Implementation of Nutrition Compact with Regional Commissioners, Dodoma: President's Office - Regional Administration and Local Government

Government of Tanzania (2019d) Mid-Term Review of the National Multisectoral Nutrition Action Plan 2016/17-2020/21, Dar es Salaam: Prime Minister's Office, Tanzania Food and Nutrition Centre and UNICEF

Government of Tanzania (2018) The Fifth Joint Multisectoral Nutrition Review Meeting (No. 2284), Dodoma: Tanzania Food and Nutrition Centre

Government of Tanzania (2017) The Fourth Joint Multisectoral Nutrition Review Meeting (No. 2263), Dodoma: Tanzania Food and Nutrition Centre

Government of Tanzania (2016a) National Multisectoral Nutrition Action Plan (NMNAP): From Evidence to Policy to Action July 2016 - June 2021, Dar es Salaam: Prime Minister's Office

Government of Tanzania (2016b) Report on the 2016 and Third Tanzania Joint Multisectoral Nutrition Review (No. 2240), Dar es Salaam: Tanzania Food and Nutrition Centre

Government of Tanzania (2015) Report on the 2015 and Second Tanzania Joint Multisectoral Nutrition Review (No. 2134), Dar es Salaam: Tanzania Food and Nutrition Centre

Government of Tanzania (2014) The First Joint Multi-Sectoral Nutrition Review (No. 2205), Dar es Salaam: Tanzania Food and Nutrition Centre

Government of Tanzania (2013) Presidential Call to the Nation for Increased Accountability in Improving Nutrition Situation in the Country, Directorate of Presidential Communications, press release, 9 May

Haddad, L.; Acosta, A.M. and Fanzo, J. (2012) 'Accelerating Reductions in Undernutrition: What Can Nutrition Governance Tell Us?', IDS In Focus Policy Briefing 22, Brighton: Institute of Development Studies (accessed 17 November 2021)

Headey, D.D.; Heckert, J.; Ndiaye, B.; Brero, M. and Assey, V. (2019) Accounting for the Rapid Reduction of Child Stunting in Tanzania over 2005-2016, IFPRI Discussion Paper 01874, Washington DC: International Food Policy Research Institute (accessed 12 November 2021)

Hoffman, B.D. (2013) Political Economy of Tanzania, Washington DC: Georgetown University

Martin Hilber, A. et al. (2016) 'Strengthening Accountability for Improved Maternal and Newborn Health: A Mapping of Studies in Sub-Saharan Africa', International Journal of Gynecology \& Obstetrics 135.3: 345-57 (accessed 12 November 2021)

Schedler, A. (1999) 'Conceptualising Accountability', in M.F. Plattner, L. Diamond and A. Schedler (eds), The Self-Restraining State: Power and Accountability in New Democracies, Boulder CO: Lynne Rienner Publishers

te Lintelo, D.J.H. (2019) Developing Subnational Scorecards for Nutrition Accountability in Tanzania, IDS Working Paper 530, Brighton: Institute of Development Studies (accessed 28 September 2021)

te Lintelo, D.J.H. and Pittore, K. (2021) 'Evaluating Parliamentary Advocacy for Nutrition in Tanzania', European Journal of Development Research 33: 735-59 (accessed 12 November 2021) 
Nutrition Accountability through Sub-National Scorecards in Tanzania - Policy Innovations and Field Realities

ten Hoope-Bender, P. et al. (2016) 'Using Advocacy and Data to Strengthen Political Accountability in Maternal and Newborn Health in Africa', International Journal of Gynecology \& Obstetrics 135.3: 358-64 (accessed 12 November 2021)

WHO (n.d.) STEPwise Approach to NCD Risk Factor Surveillance (STEPS), World Health Organization website (accessed 12 November 2021) 
IDS

T +44 (0) 1273606261

E ids@ids.ac.uk

W www.ids.ac.uk

T @IDS UK

F facebook.com/idsuk
Irish Aid

T +353 (1) 4082000

w www.irishaid.ie

T @Irish_Aid 